Research Article

\title{
Severe Weather Events over Southeastern Brazil during the 2016 Dry Season
}

\author{
Amanda Rehbein, ${ }^{1}$ Lívia Márcia Mosso Dutra, ${ }^{1}$ Tercio Ambrizzi $\mathbb{D D}^{1}{ }^{1}$ \\ Rosmeri Porfírio da Rocha, ${ }^{1}$ Michelle Simões Reboita, ${ }^{2}$ \\ Gyrlene Aparecida Mendes da Silva $\left(\mathbb{D},{ }^{3}\right.$ Luiz Felippe Gozzo, ${ }^{4}$ \\ Ana Carolina Nóbile Tomaziello, ${ }^{1}$ José Leandro Pereira Silveira Campos, ${ }^{1}$ \\ Victor Raul Chavez Mayta, ${ }^{1}$ Natália Machado Crespo, ${ }^{1}$ Paola Gimenes Bueno (D), \\ Vannia Jaqueline Aliaga Nestares, ${ }^{1}$ Laís Tabosa Machado, ${ }^{1}$ Eduardo Marcos De Jesus, ${ }^{1}$ \\ Luana Albertani Pampuch, ${ }^{5}$ Maria de Souza Custódio, ${ }^{4}$ and Camila Bertoletti Carpenedo ${ }^{6}$ \\ ${ }^{1}$ Departamento de Ciências Atmosféricas, Instituto de Astronomia, \\ Geofísica e Ciências Atmosféricas da Universidade de São Paulo, São Paulo, SP, Brazil \\ ${ }^{2}$ Instituto de Recursos Naturais da Universidade Federal de Itajubá, Itajubá, MG, Brazil \\ ${ }^{3}$ Departamento de Ciências do Mar da Universidade Federal de São Paulo, São Paulo, SP, Brazil \\ ${ }^{4}$ Departamento de Física da Universidade Estadual Paulista Júlio de Mesquita Filho, Campus de Bauru, SP, Brazil \\ ${ }^{5}$ Instituto de Ciência e Tecnologia da Universidade Estadual Paulista Júlio de Mesquita Filho, Campus de São José dos Campos, \\ São Paulo, SP, Brazil \\ ${ }^{6}$ Instituto de Geografia da Universidade Federal de Uberlândia, Uberlândia, MG, Brazil
}

Correspondence should be addressed to Tercio Ambrizzi; ambrizzi@model.iag.usp.br

Received 27 December 2017; Revised 3 April 2018; Accepted 18 April 2018; Published 10 June 2018

Academic Editor: Anthony R. Lupo

Copyright $\odot 2018$ Amanda Rehbein et al. This is an open access article distributed under the Creative Commons Attribution License, which permits unrestricted use, distribution, and reproduction in any medium, provided the original work is properly cited.

\begin{abstract}
Southeastern Brazil is the most populated and economically developed region of this country. Its climate consists of two distinct seasons: the dry season, extending from April to September, the precipitation is significantly reduced in comparison to that of the wet season, which extends from October to March. However, during nine days of the 2016 dry season, successive convective systems were associated with atypical precipitation events, tornadoes and at least one microburst over the southern part of this region. These events led to flooding, damages to buildings, shortages of electricity and water in several places, many injuries, and two documented deaths. The present study investigates the synoptic and dynamical features related to these anomalous events. The convective systems were embedded in an unstable environment with intense low-level jet flow and strong wind shear and were supported by a sequence of extratropical cyclones occurring over the Southwest Atlantic Ocean. These features were intensified by the Madden-Julian oscillation (MJO) in its phase 8 and by intense negative values of the Pacific South America (PSA) 2 mode.
\end{abstract}

\section{Introduction}

Climate and weather components that affect directly the population and economy of Southeastern Brazil $[1,2]$ have been widely studied in recent years, as well as the large-scale forcings from tropical and extratropical origins. It is well known that the climate of Southeastern Brazil is influenced by the South America monsoon system, where during the summer (Dec-Jan-Feb), there is a predominance of intense convective precipitation due to the availability of plentiful heat and moisture over the tropical region [3]. This intense convective precipitation delineates a cloud corridor known as the South Atlantic Convergence Zone (SACZ), which extends from the southwest Amazon Basin and through Southeast Brazil, reaching the Atlantic Ocean [4]. From the beginning of autumn until midspring, the frequency of SACZ episodes 
decreases, initiating the dry period over Southeastern Brazil [5]. Moreover, it is during this period that the South Atlantic Subtropical Anticyclone (SASA) reaches its most westerly position, extending over Southeastern Brazil, which impedes the passage of frontal systems [6]. Therefore, during this period, the precipitation events are normally quick, isolated, and not intense.

During the dry season of 2016, there were 9 consecutive atypical days (May 30 to June 07, 2016) with thunderstorms, tornadoes, and at least one microburst over Southeastern Brazil. These phenomena caused floods, smashed houses, personal injuries, and two documented deaths (http:// g1.globo.com/sao-paulo/sorocaba-jundiai/noticia/2016/06/ meteorologistas-analisam-se-tornado-causou-destruicaoem-jarinu.html and http://www.saoroquenoticias.com.br/ noticia.asp?idnoticia $=16053$ ). These atypical weather events affected mainly the southern part of Southeastern Brazil, with the most severe conditions occurring over the cities of Campinas, Jarinu, and São Roque, which are close to city of São Paulo in São Paulo State. In Campinas, a probable microburst occurred on June 05 between 00:00 and 00:30 Local Time (LT; Rachel Ifanger Albrecht, personal communication, 2016). At Jarinu on June 05 at about 21 LT and at São Roque on June 06 in the late afternoon, the occurrences of tornadoes were confirmed by analysis of damage by local meteorological institutes and civil defense, besides being observed in the meteorological radar data (Rachel Ifanger Albrecht, personal communication, 2018). Precipitation anomalies from May 30 to June 07 reached values of around $200 \mathrm{~mm}$ in Southeastern Brazil, in a region comprising São Paulo State and parts of other surrounding states (Figure 1). For instance, at the meteorological station of the Institute of Astronomy, Geophysics and Atmospheric Science of the University of Sao Paulo (IAG/USP), located in the southern part of the city of São Paulo, the climatological precipitation for the period of 1981 to 2010 is $55.5 \mathrm{~mm}$ for the entire month of June. In the first 7 days of June 2016, at this station, the total precipitation was $175.4 \mathrm{~mm}$ (316\% of the climatological value for the entire month).

The aims of the present study are (a) to investigate the dynamic forcings associated with those severe weather and extreme rainfall events over Southeastern Brazil in the dry season of 2016 and (b) to verify whether or not the mostused forecast models in Brazil predicted this period of intense precipitation. The datasets and methodology used are described in Section 2; Section 3 presents the synoptic discussion, low-frequency analysis, and the model forecasts results; and the concluding remarks are given in Section 4.

\section{Data and Methods}

The period of analysis is May 30 to June 07, 2016, and the region of interest covers the area between latitudes $25^{\circ} \mathrm{S}$ to $19^{\circ} \mathrm{S}$ and longitudes $53^{\circ} \mathrm{W}$ to $42^{\circ} \mathrm{W}$ (red box in Figure 1), where the most intense precipitation and severe weather events were registered.

2.1. Synoptic and Thermodynamic Analysis. The synoptic fields were constructed using data from the ERA-Interim

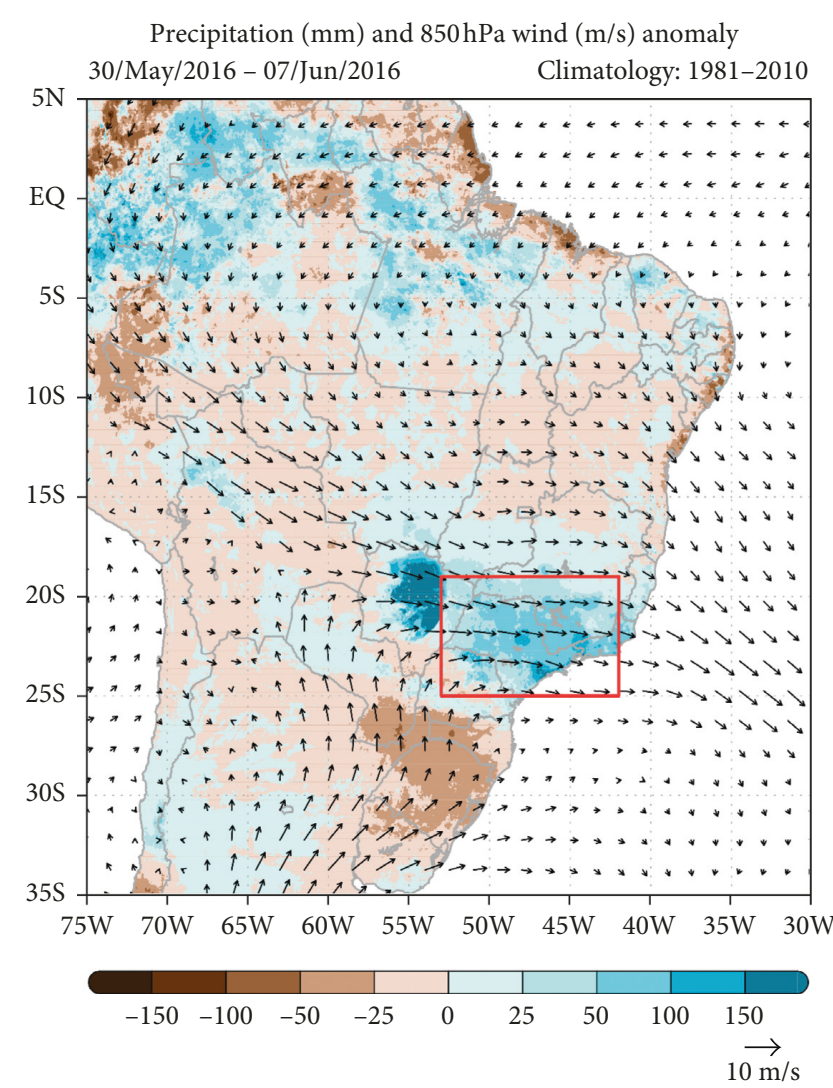

Figure 1: Precipitation anomalies $(\mathrm{mm})$ and $850 \mathrm{hPa}$ wind composite $\left(\mathrm{m} \cdot \mathrm{s}^{-1}\right)$ for May 30 to June 07,2016 . The blue (brown) colors indicate the positive (negative) rain anomalies, and the red box indicates the area of study. The anomalies were calculated using the 30-year period, 1981 to 2010.

reanalysis [7] from the European Centre for Medium-Range Weather Forecasts (ECMWF). These data are available every six hours $(0000,0006,1200$, and 1800 UTC) with spatial resolution of $0.75^{\circ}$, for various pressure levels [7]. We analyzed the synoptic fields at low, middle, and upper levels at each available time; however, for brevity, only the 1200 UTC fields are presented here.

Infrared satellite images (about $10.7 \mu \mathrm{m}$ ) with $4 \mathrm{~km}$ and 30 minutes of spatial and temporal resolution, respectively, are from the Geostationary Operational Environmental Satellite (GOES-13; Janowiak et al. [8]) and were made available by the CPC/NCEP/NWS (Climate Prediction Center/National Centers for Environmental Prediction/National Weather Service) via ftp://ftp.cpc.ncep.noaa.gov/precip/global_full_ res_IR/.

Five thermodynamic indices (Convective Available Potential Energy-CAPE, Convective Inhibition-CIN, $K$ index, Total Totals-TT, and Showalter) are used to characterize the environmental instability. Moreover, two kinematic indices (sweat and vertical shear of horizontal wind-here termed "wind shear") are also presented because when their values are strong, the environment is favorable to severe weather events $[9,10]$ and to the formation of stronger convective supercells [11]. The instability and kinematic indices were obtained for a point $\left(23^{\circ} \mathrm{S} / 47^{\circ} \mathrm{W}\right)$ representative of the severe storm 
sites-Campinas, Jarinu, and São Roque. This point is located less than $60 \mathrm{~km}$ from these sites. In the literature, a distance of up to $180 \mathrm{~km}$ is used for the representativeness of such surveys $[12,13]$. The Convective Available Potential Energy (CAPE) and Convective Inhibition (CIN) were obtained from the Global Forecast System (GFS) model analysis with spatial resolution of $0.5^{\circ}$ and available for $0000,0600,1200$, and 1800 UTC. The $K$ index [14], Total Totals (TT; Miller [15]), Showalter [16], wind shear, and Sweat index were calculated using the GFS analysis data. The Sweat index is adapted from Miller [15] to Southern Hemisphere wind conditions following Nascimento [10].

2.2. Climate Analysis. The weather and climate in South America are influenced by relatively well-known teleconnection patterns of tropical and extratropical origins that we can observe and measure through indices and statistical analysis. In this study, we investigated the influence of the most important atmospheric and oceanic phenomena that can affect the weather over the Southeastern Brazil: Madden Julian Oscillation [17], Pacific South America pattern, first and second modes [18, 19]; Indian Ocean Dipole (IOD; [20-22]); Southern Annular Mode [23]; and blocking events [24, 25].

The MJO is triggered in the Indian and Pacific Oceans and propagates eastward over the tropical region with a cycle of about 30 to 60 days [26]. During its propagation, it comprises regions with enhanced and suppressed convection. In São Paulo, the most favorable conditions for convection occur with suppression of convection over Indonesia, when the MJO is in its phases 8 and 1, as shown by Jones and Carvalho [17]. Here, to better understand the influence on the extreme rainfall variability over Southeastern Brazil by the eastward-propagating MJO-related large-scale convective and circulation envelope, we have constructed lagged/lead composites for the 0.21 sigma-level (approximately $200 \mathrm{hPa}$ ) velocity potential and outgoing longwave radiation (OLR) anomalies.

The velocity potential was obtained from National Centers for Environmental Prediction/National Center for Atmospheric Research (NCEP/NCAR; Kalnay et al. [27]) and the OLR field from the High Resolution Infrared Radiation Sounder (HIRS; Lee et al. [28]). Daily anomalies of OLR and velocity potential were calculated at every grid point by subtracting the long-term average (1979-2015) in order to remove the seasonal cycle. The intraseasonal signals are isolated from the OLR daily anomalies by applying Lanczos bandpass filter [29] using cutoff frequencies at 20 and 96 days. To assemble the composites, we considered the Wheeler and Hendon [30] real-time multivariate MJO (RMM) index for our period of analysis. This index is available at the Centre for Australian Weather and Climate Research website (see: http://www.bom.gov.au/climate/mjo/) and is based on a pair of empirical orthogonal functions (EOFs) of the combined fields of near-equator averaged $850 \mathrm{hPa}$ zonal wind, $200 \mathrm{hPa}$ zonal wind, and satelliteobserved outgoing longwave radiation (OLR) data [30]. The evolution of these anomalies from "day -12 " to "day +9 ", where "day 0 " represents the active phase (enhanced convection) over tropical South America, is shown in Figure 8. RMM amplitude in phase 8 reaches its maximum value at "day 0 ," which means that the association between rainfall anomalies and MJO passage over Southeastern Brazil was strong.

The PSA modes are teleconnection patterns extending poleward and eastward over the Pacific Ocean [31], modulating the circulation and precipitation anomalies over South America [32]. PSA teleconnection patterns consist of two distinct modes: PSA 1, related to the El Niño Southern Oscillation (ENSO; Karoly [31]) and PSA 2, associated with the MJO during the winter [18]. Both of them have impacts on the climate of South America, and consequently on the rainfall intensity and distribution over São Paulo state. The PSA modes are defined as the first and second leading rotated principal component modes of the $200 \mathrm{hPa}$ stream function anomaly, respectively $[18,32]$; these patterns are also presented in other time scales such as pentads and annual [32-34]. In this study, both PSA modes were computed using ERA-Interim reanalysis for the $200 \mathrm{hPa}$ pentad stream function anomaly data. The covariance matrix was obtained through the extraction of the annual cycle computed with the climatology of 1981-2010 as a basis period.

Saji et al. [35] showed that the anomalous warming of the tropical Indian Ocean due to low level evaporation can lead to divergence in the upper troposphere, sourcing Rossby wave trains propagating from the Indo-Pacific region towards the South Atlantic Ocean in an arch-like trajectory. Taschetto and Ambrizzi [22] showed that anomalous warming throughout the Indian Ocean Basin can excite Rossby wave trains moving towards the South Atlantic, and also amplifying El Niño patterns in the precipitation over the South American continent, for the austral autumn season (March-May). In order to explore the effects of the Indian Ocean on South American precipitation, the Indian Ocean Dipole (IOD; Saji et al. [36]; Webster et al. [37]), that is, the difference between the Eastern and Western Basin sea surface temperature anomaly (SSTa), is computed through the extraction of the annual cycle based on the 1981-2010 climatology, for 36 years (1980-2016) of ERA-Interim data.

The SAM, also known as Antarctic Oscillation (AAO), is the main mode of extratropical circulation variability in the Southern Hemisphere. It consists of zonally symmetric structures, with geopotential height perturbations of opposing signs in Antarctica and in the surrounding zonal ring centered near $45^{\circ}$ latitude [38]. Reboita et al. [23] observed that during negative SAM phases, the cyclone trajectories are northward of their positions during the positive phase, and in the South America and South Atlantic sectors, there is intense frontogenetic activity and a positive precipitation anomaly over southeastern South America, which influences the weather in São Paulo. To monitor SAM, we used the daily AAO index available on the Climate Prediction Center/National Oceanic and Atmospheric Administration (CPC/NOAA) website (http://www.cpc.ncep.noaa.gov/ products/precip/CWlink/daily_ao_index/aao/aao.shtml). This index is constructed using $700 \mathrm{hPa}$ geopotential height anomalies projected onto the leading EOF mode [39]. To define the phase of the SAM, we use a methodology similar 


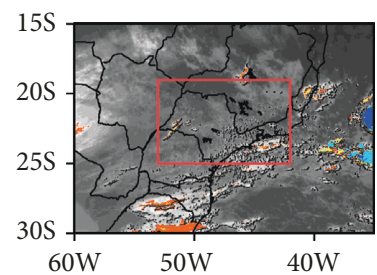

(a)

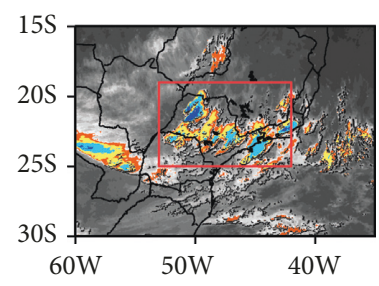

(e)

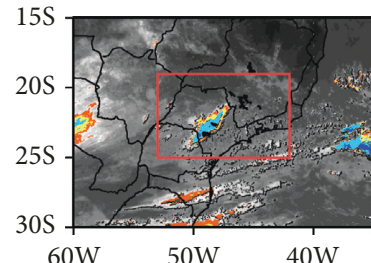

(b)

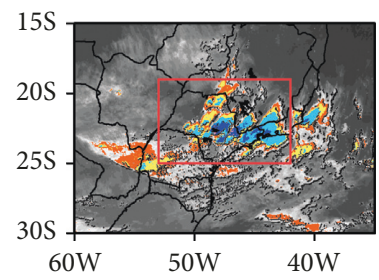

(f)

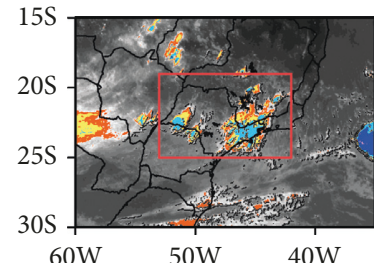

(c)

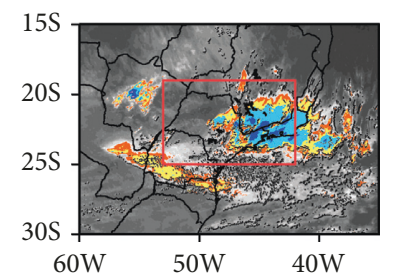

(g)

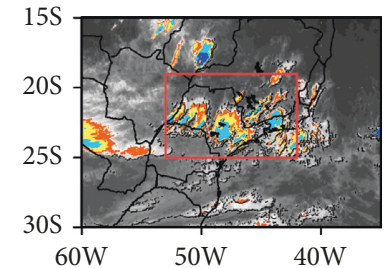

(d)

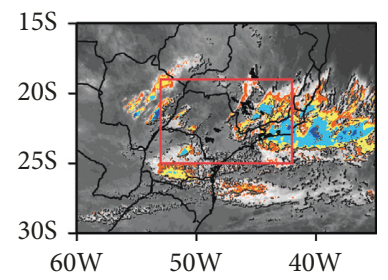

(h)

Figure 2: GOES-13 enhanced infrared images on June 04, 2016, at (a) 1200 UTC, (b) 1500 UTC, (c) 1800 UTC, and (d) 2100 UTC; and on June 05, 2016, at (e) 0000 UTC, (f) 0300 UTC, (g) 0600 UTC, and (h) 0900 UTC.

to Reboita et al. [23], in which values above (below) one standard deviation indicate the positive (negative) phase. The standard deviation value of the daily SAM time series from 1979 to 2015 is equal to 1.4, and thus values between \pm 1.4 indicate the neutral phase.

Atmospheric blocking episodes are due to quasistationary planetary waves of large amplitude [40], persisting from days to a few weeks, leading to episodes of prolonged extreme weather conditions over some areas. Over the Southeastern Pacific, Southern Atlantic and Oceania, the lowpressure anomalies occurring on the equatorial flank of the blocking pattern favor the development of transient systems that may cause precipitation as they move eastward (Mendes et al. [41]). The resulting impacts on temperature and precipitation are most frequently observed over Southern Brazil, but they can also influence our region of interest (Southeastern Brazil; Mendes et al. [41]). In the latter case, Mendes et al. [41] observed that southeastern Pacific blocking has higher impact on precipitation in austral summer and spring (wet season), while the Atlantic blocking affects precipitation in austral autumn and winter (dry season).

For the identification of blocking events over the Southern Hemisphere, we used the objective method of Tibaldi et al. [42], modified from Lejeñas [43]. This method was adapted to a smaller horizontal spacing of the ERAInterim reanalysis $\left(1.5^{\circ} \times 1.5^{\circ}\right.$ of horizontal resolution) instead of $3.75^{\circ} \times 3.75^{\circ}$ used by Tibaldi et al. [42] and stratified into five bands of latitudes, according to Oliveira et al. [25]. For an episode to be characterized as a blocking event, it must persist for at least 3 days [25, 44, 45].

The ENSO signal was not evaluated in this work because the São Paulo (SP) region is located in between the two sectors of South America in El Niño (EN), and La Niña (LN) episodes usually affect the observed precipitation with opposing contributions. For instance, during EN conditions, there is increased precipitation over the southeastern sector of South America (including Southern Brazil) and reduced precipitation over the northern/northeastern sector of South
America (including northern/northeastern Brazil; Grimm and Ambrizzi [46]; da Rocha et al. [47]). Given its location, the SP region is considered to be a transition region where the effect of ENSO could be either to increase or reduce precipitation [48].

\section{Results and Discussions}

3.1. Synoptic Analysis. A rainfall anomaly averaging $47 \mathrm{~mm}$ occurred over the SP region (red box in Figure 1) during the period May 30 to June 07, 2016. Figure 1 shows that in specific regions, rainfall anomalies reached more than $100 \mathrm{~mm}$ over these 9 days. The satellite images show convective systems forming in the western SP region and moving eastward throughout their life cycle (see, e.g., Figure 2). In addition, some convective systems were generated northwest of the SP region propagating along the low-level mean flow and growing as they moved into the region. Each system had its own lifetime, starting, and developing preferentially during early afternoon (1200 to 1500 LT). Figure 1 also shows that the predominant wind at $850 \mathrm{hPa}$ flowed from the southern Amazon Basin into the SP region. This is the same as the configuration observed by Morales et al. [49] on days with thunderstorms in the city of São Paulo.

Figures 3(a)-3(d) show vertical profiles of horizontal temperature advection, divergence of the horizontal wind, pressure vertical velocity (omega), and moisture convergence averaged over the SP region, from May 30 to June 07, 2016, every 6 hours. Overall, warm-air advection occurred at all levels of the troposphere, peaking on June 05 (Figure 3(a)) when two of the most severe events were reported (microburst at Campinas, SP, and tornado at Jarinu, SP). This warm advection contributes to increased instability over the $\mathrm{SP}$ region and is associated with a northerly mean flow, as further discussed in this section. On June 07, the last day of the observed anomalous precipitation over the SP region, intense cold advection occurred in the lower troposphere (Figure 3(a)), associated with a change in the direction of the 


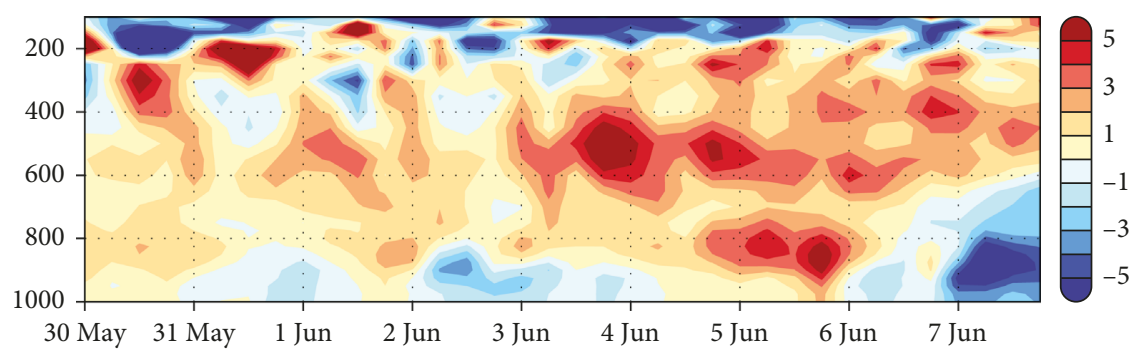

(a)

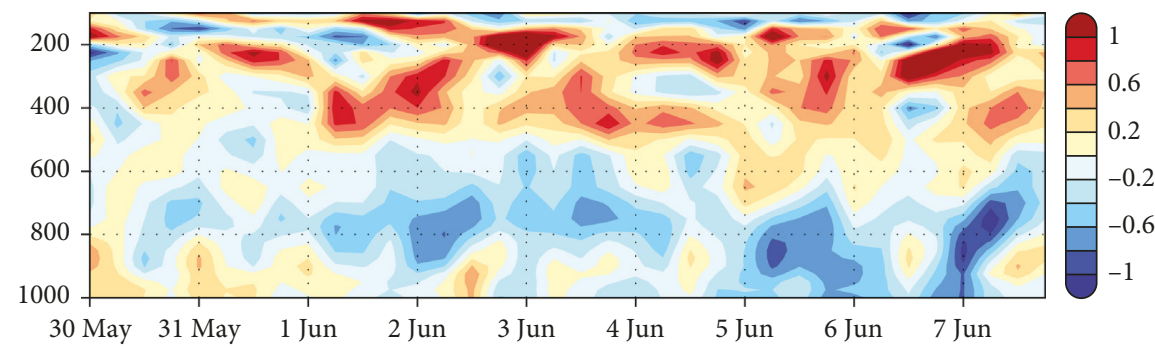

(b)

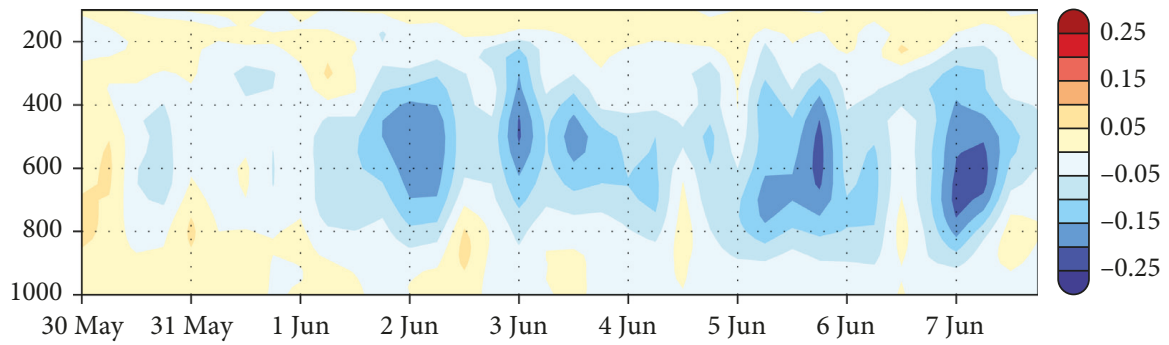

(c)

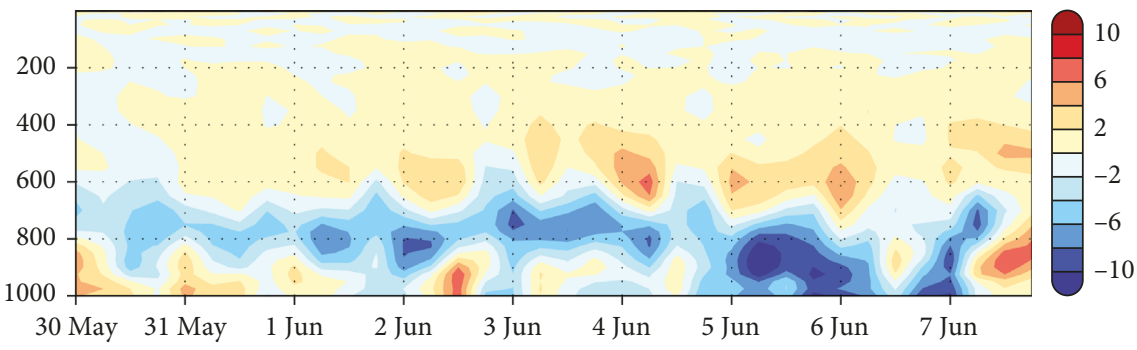

(d)

FiguRE 3: Vertical profiles of (a) horizontal temperature advection $\left(\mathrm{K} \cdot \mathrm{day}^{-1}\right)$, (b) divergence of the horizontal wind $\left(10^{-5} \cdot \mathrm{s}^{-1}\right),(\mathrm{c}) \mathrm{pressure}$ vertical velocity (or omega; $\mathrm{Pa} \cdot \mathrm{s}^{-1}$ ), and (d) moisture divergence $\left(10^{-5} \cdot \mathrm{g}^{\mathrm{kg}} \mathrm{kg}^{-1} \cdot \mathrm{s}^{-1}\right.$ ) averaged over the SP region, from May 30 to June 07, 2016, every 6 hours.

mean flow over the region at these levels. Convergence in the lower troposphere and divergence in the upper troposphere occurred during all days analyzed (Figure 3(b)), favoring upward motion over the SP region (Figure 3(c)). At lower and middle levels (up to $600 \mathrm{hPa}$ ), moisture convergence occurred on all days (except June 07; Figure 3(d)), indicating favorable conditions for the formation of convective systems in the SP region. The general pattern described above was the reverse of that of the week prior to May 30 and after June 07 (not shown), when there was no anomalous precipitation over the SP region.

The lower-level moisture convergence and warm-air advection over the SP region occurred in association with the South American low-level jet (SALLJ) (east of the Andes), which comes from tropical latitudes over the south Amazon Basin towards the subtropics, exiting over the SP region. This SALLJ developed around 0600 UTC on May 30 (not shown) and was sustained until 0000 UTC on 07 June. It can be seen as a northwesterly band of maximum wind intensity at $850 \mathrm{hPa}$ in association with a poleward transport of warm and moist air (Figure 4). Commonly, days with thunderstorms over the city of São Paulo (about $100 \mathrm{~km}$ away from where the severe events occurred) are accompanied by strong northerly winds [49].

The SALLJs are observed throughout the year but are more frequent and intense during the warm season (NDJF) when the northeast trade winds in the equatorial western Atlantic flow towards the Amazon Basin [50]. The trade 


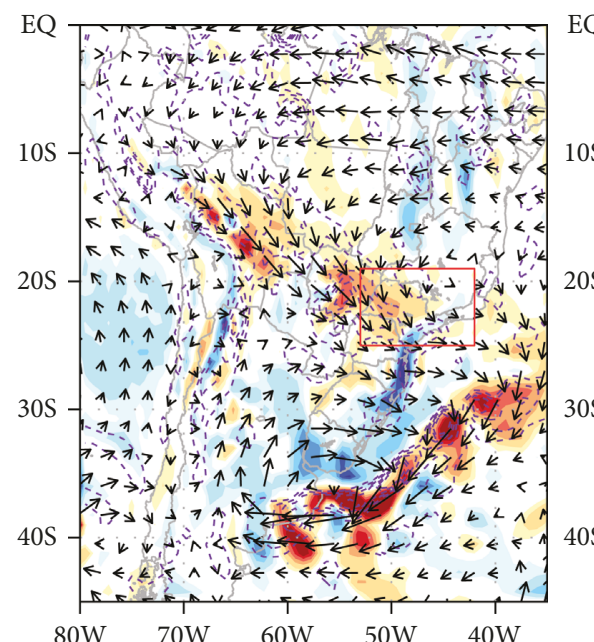

(a)

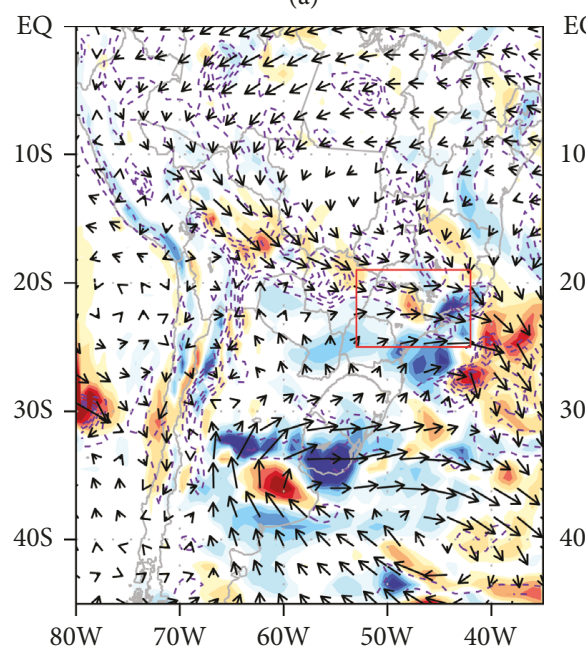

(d)

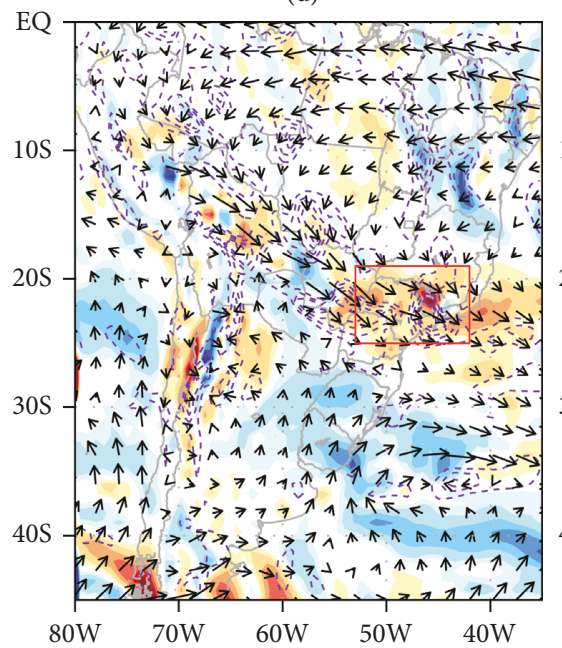

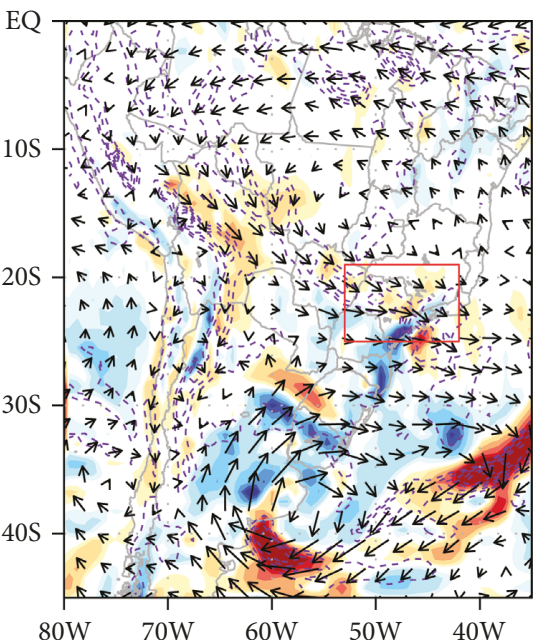

(b)

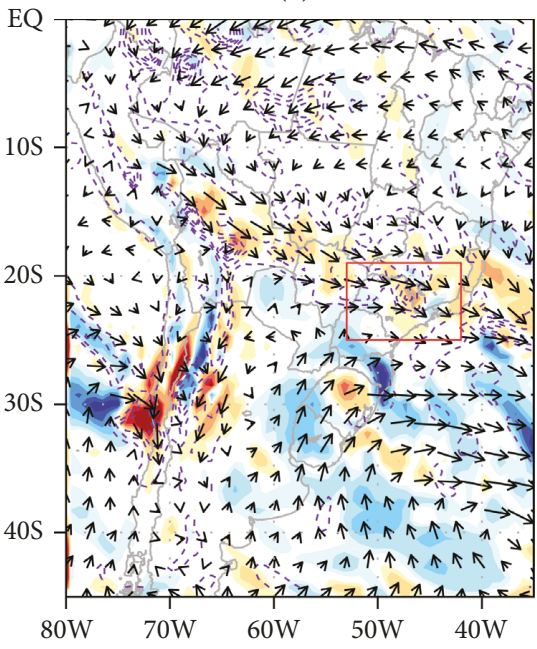

(e)

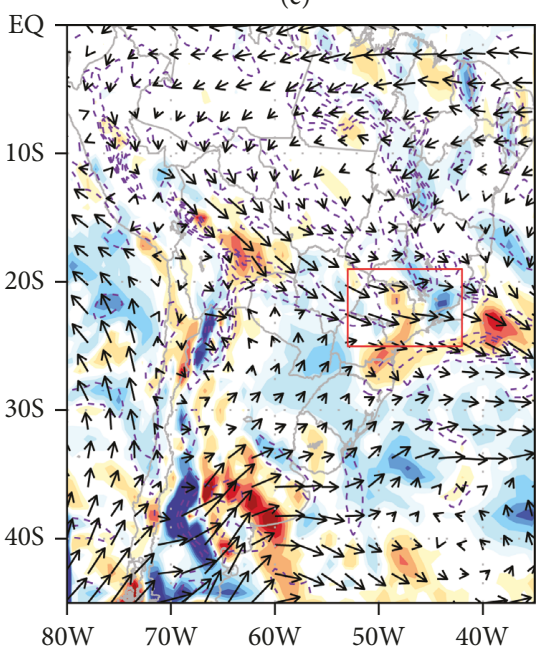

(h)

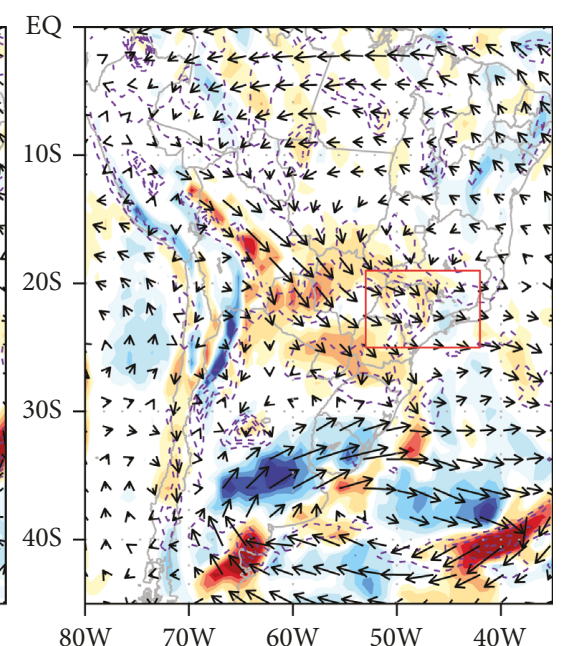

(c)

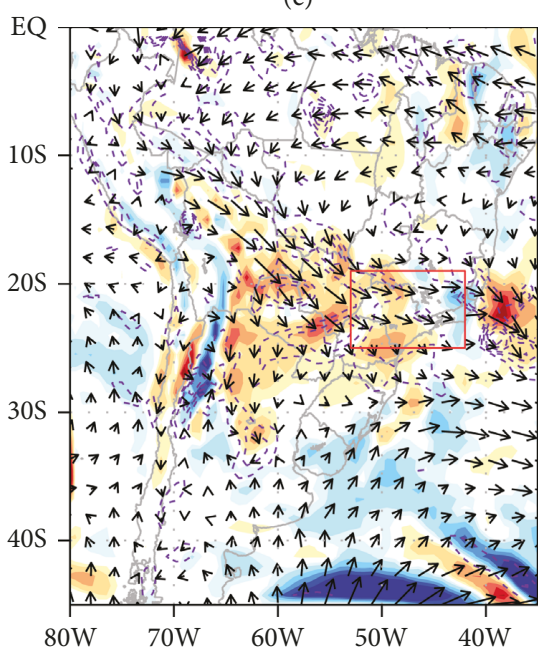

(f)

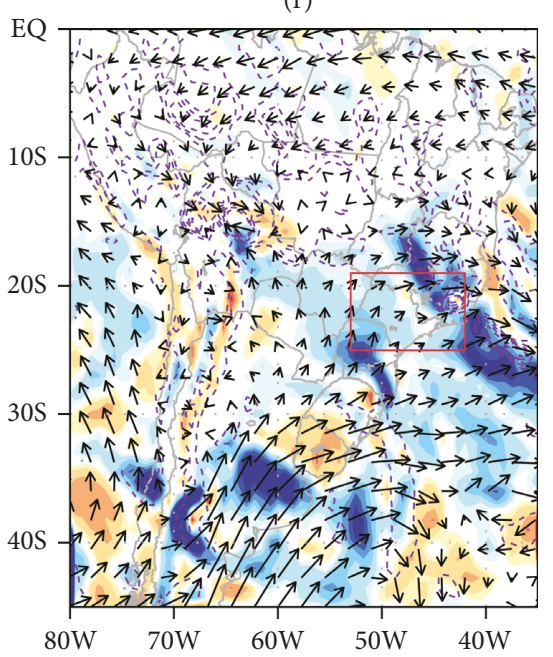

(i)

\begin{tabular}{|l|l|l|l|l|l|l|l|l|l|l|l|l}
\hline & & & & & & & & & & & & \\
\hline
\end{tabular}

Figure 4: Horizontal temperature advection (shaded; $\mathrm{K} \cdot \mathrm{day}^{-1}$ ), moisture flux convergence (purple contours every $10 \times 10^{-5} \mathrm{~g} \cdot \mathrm{kg}^{-1} \cdot \mathrm{s}^{-1}$ from $5 \times 10^{-5}$ to $55 \times 10^{-5} \mathrm{~g} \cdot \mathrm{kg}^{-1} \cdot \mathrm{s}^{-1}$ ), and horizontal wind (vectors; $\mathrm{m} \cdot \mathrm{s}^{-1}$ ) at $850 \mathrm{hPa}$ at $1200 \mathrm{UTC}$ on (a) $30 \mathrm{May}$, (b) $31 \mathrm{May}$, (c) $01 \mathrm{June}$, (d) 02 June, (e) 03 June, (f) 04 June, (g) 05 June, (h) 06 June, and (i) 07 June, 2016. 
winds are deflected toward the southeast as they approach the mountain barriers and then converge with the flow from the western branch of the South Atlantic Subtropical High $(\mathrm{SASH})$, producing strong wind speeds at low levels and convective development over the exit region of the jet (see, conceptual model presented in Marengo et al. [51] and their Figure 1). This exit region is located typically over Southern Brazil-Northern Argentina as described in Marengo et al. [51]. During May 30 to June 06, 2016, however, the SALLJ was active northeastward of its typical position, such that its exit was located over the SP region instead of Southern Brazil (Figure 4). This displacement in the jet direction was likely driven by the intense extratropical cyclonic activity over the Atlantic Ocean adjacent to the South American coast during the days analyzed (Figure 5). This activity consisted of two main extratropical cyclones plus three secondary cyclones forming and acting along the southeastern coast of South America. The cyclonic (clockwise) circulation predominant over the southwestern Atlantic Oceanfavored the blocking - by the northwesterly SALLJ-of the advection of cold and dry air from higher latitudes into eastern Argentina and Southern Brazil (Figure 4). At 0000 UTC on June 07, a cold front finally penetrates the continent (figure not shown), reaching the southern Amazon region and weakening the SALLJ, by means of advection from a colder and dryer air mass into the rear of the frontal zone (Figure 4(i)). These persistent low-level patterns (Figures 4 and 5) all seem to be unrelated to a persistent subtropical jet at high-levels (Figure 6).

During the period of interest, atmospheric instability was calculated in terms of various thermodynamic (Figures $7(\mathrm{a})-7(\mathrm{e})$ ) and kinematic (Figure $7(\mathrm{f})$ and $7(\mathrm{~g})$ ) indices. The $K$ index indicates high probability (above $80 \%$ ) of storm occurrence from 1200 UTC on May 31 to 0000 UTC on June 07 (except at 1200 UTC on June 02 and 03; Figure 7(a)). After this period, the $K$ index decreased substantially. The Total Totals index was high (above $46^{\circ} \mathrm{C}$ ) during most of our period of interest (Figure $7(\mathrm{~b})$ ), indicating some scattered storms. From 0000 UTC on June 04 to 1200 UTC on June 06 , the warm air advection at middle levels was greater than on other days (Figure 3(a)), decreasing the values of the Total Totals during this period. The Showalter index indicated the possibility of storms, remaining most of the time below $1^{\circ} \mathrm{C}$ (Figure $7(\mathrm{c})$ ). However, it did not match the thresholds for tornados (below $-6^{\circ} \mathrm{C}$ ) in the days in which this phenomenon happened (June 05 and 06). This is possibly due to the strong midlevel warm advection over the SP region during these days (Figure 3(a)), which contributed to raising the temperature at $500 \mathrm{hPa}$. It is interesting to note that the CAPE was relatively low (Figure 7(d)), CIN was relatively intense (Figure 7(e)), and the wind shear was above the traditional threshold to favor rotating supercells $\left(15 \mathrm{~m} \cdot \mathrm{s}^{-1}\right.$; Figure $\left.7(\mathrm{f})[10]\right)$. The severe weather observed during these days is the characteristic of the cold season, where there is usually low thermodynamic convective potential but strong wind shear (an example of such a type of event in the United States is presented in Markowski and Straka [52]). The wind shear was high even after the period of interest because of the influence of the jet streams on those days (Figure (6)). The Sweat index increased from May 30 to June 6; however, it did not reach the thresholds for the development of severe storms in the United States (above 300; Figure 7(g)). Other studies in Brazil have also found that some thermodynamic and kinematic indices are indicative of the instability of a given region; however, they may not reach established thresholds of severity even when severe weather occurs $[53,54]$.

3.2. Low-Frequency Analysis. The following analysis and discussions cover the contribution of climate indices (Table 1) and planetary-scale influence on the severe rain event studied in the present paper.

3.2.1. The Influence of the Madden-Julian Oscillation. Anomalous upper-level velocity divergence (represented by negative velocity potential anomalies-dashed lines in Figure 8-had been established over tropical South America by "day -9 " (May 28) and persisted to "day +3 " (June 09), favoring upward motion mainly between "day -3 " (June 03) and "day 0 " (June 06), the period of the most intense rainfall events over the state of Sao Paulo. Thus, the OLR pattern showed enhanced convection over southeastern South America and the adjacent Atlantic Ocean toward the southern Amazon basin, resembling the austral winter situation with the active MJO phase over South America (e.g., [55]). In addition, "day 0" was when the RMM reached phase 8 and its amplitude began to increase. As pointed out in previous studies (e.g., Jones and Carvalho 2012 $[17,56,57])$, phase 8 and phase 1 favor convection over tropical South America. Even though phase 1 favors convection over tropical South America and the following days were in that phase, it was not sufficient to favor convection over the SP region because, as shown by the synoptic analysis, and on June 07 , the atmospheric environment over this region began to stabilize, after the cold front passage, with cold and dry air being advected from the south.

Upper-level tropical convergence (represented by positive velocity potential anomalies (Figure 8)) progresses eastward from the western tropical Pacific from "day -12 " (May 25) and arrives in tropical South America by "day +9 " (June 15), indicating the end of the active MJO period over tropical South America. It is noteworthy that the evolution of the MJO influence (onset-peak-demise) has a period of approximately 10 days (from "day -6 " to "day +3 "), average duration of the MJO passage over South America [58].

3.2.2. Pacific South America Mode. The dominant mode of low-frequency climate variability for the last pentad of May and first pentad of June 2016 was the PSA 2 mode, presenting negative values below 2 standard deviations (Table 1); this possibly results from a combination of ENSO influence in the interannual band [31] and tropical convection associated with the MJO in the intraseasonal band [18]. This strongly negative value of PSA 2 during late May/early June 2016 likely contributed to the persistent cyclogenetic activity over the Atlantic near the South 


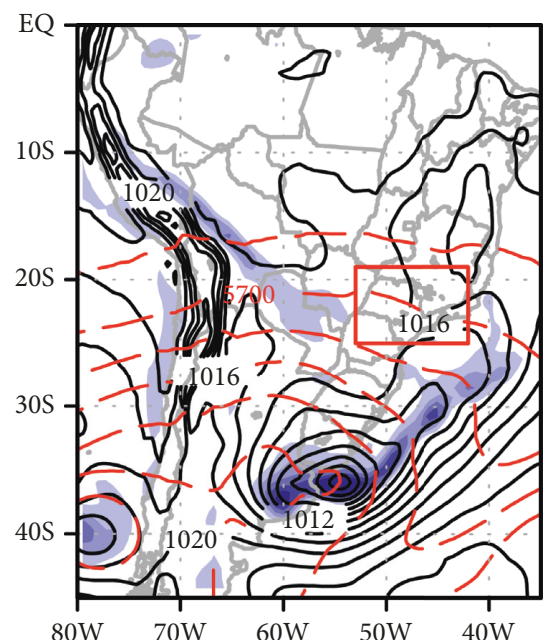

(a)

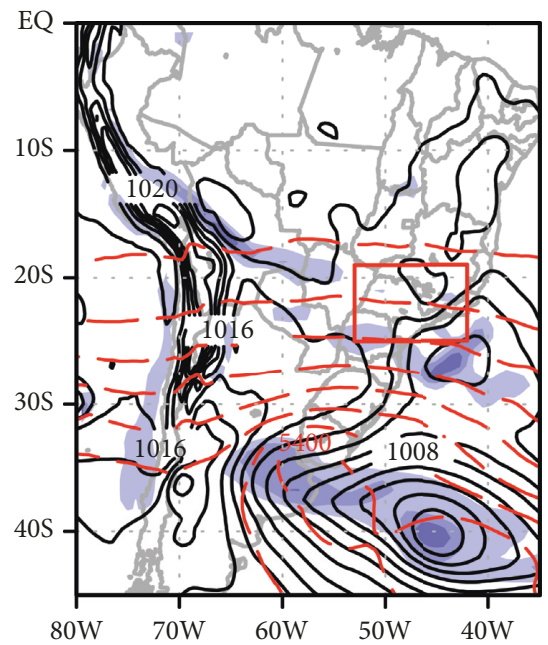

(d)

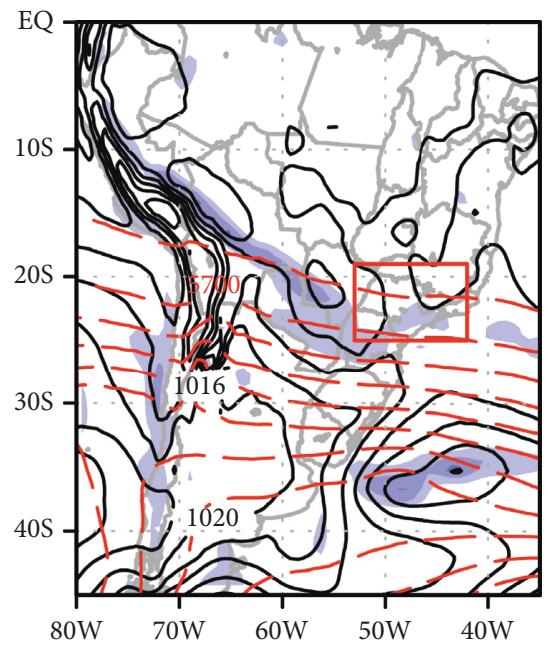

(g)

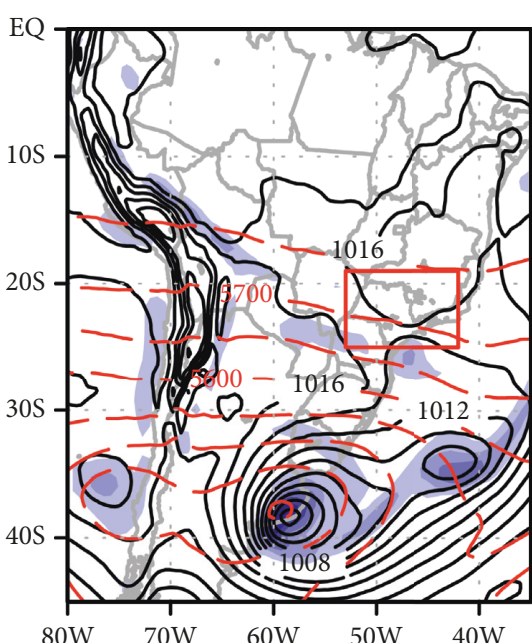

(b)

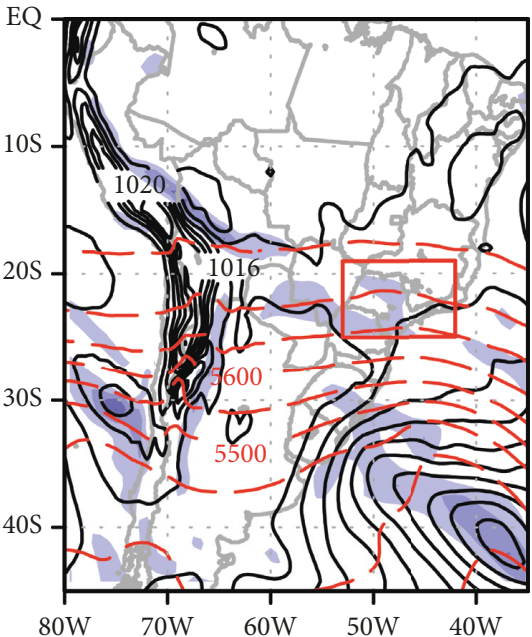

(e)

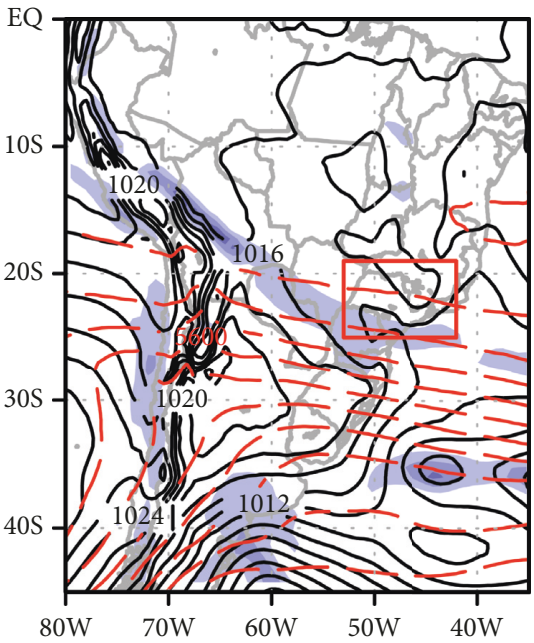

(h)

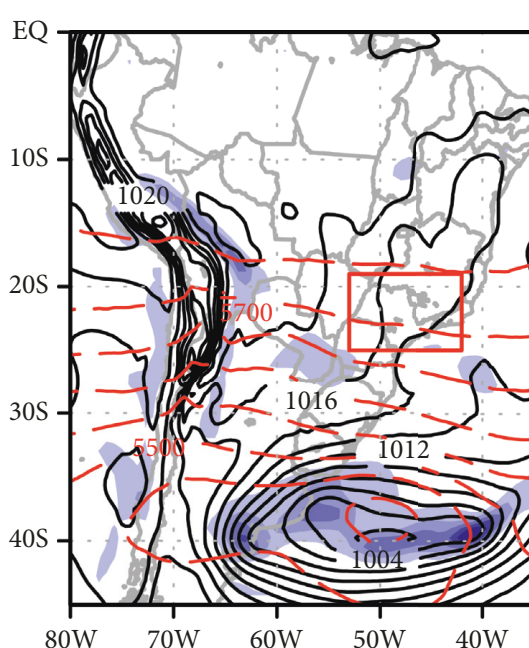

(c)

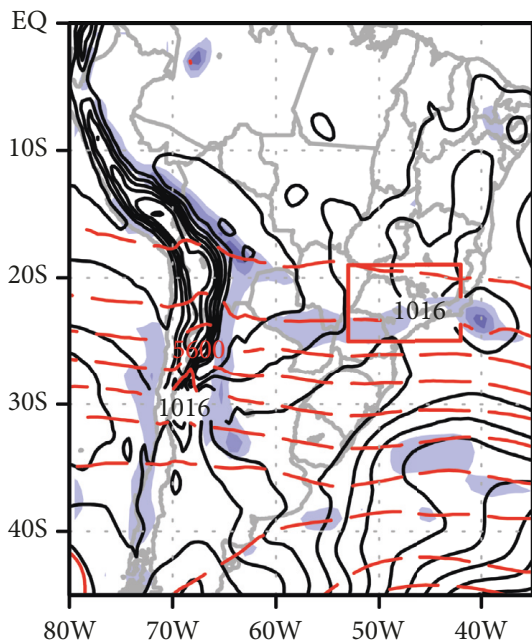

(f)

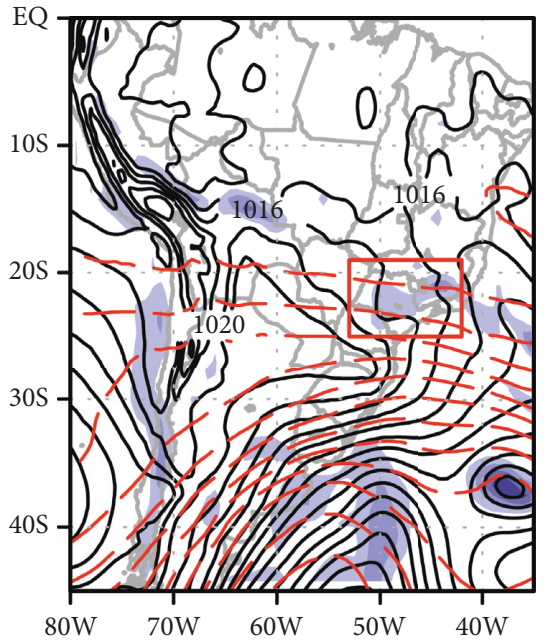

(i)

$\begin{array}{ll}-22 & -18\end{array}$

$-14$

$-10$

$-2$

Figure 5: Mean sea level pressure (black contours; hPa), geopotential height (red-dashed contours; gpm), and relative vorticity (shaded; $10^{-5} \cdot \mathrm{s}^{-1}$ ) at $850 \mathrm{hPa}$ at $12 \mathrm{UTC}$ on (a) $30 \mathrm{May}$, (b) $31 \mathrm{May}$, (c) 01 June, (d) 02 June, (e) 03 June, (f) 04 June, (g) $05 \mathrm{June}$, (h) $06 \mathrm{June}$, and (i) 07 June, 2016. 


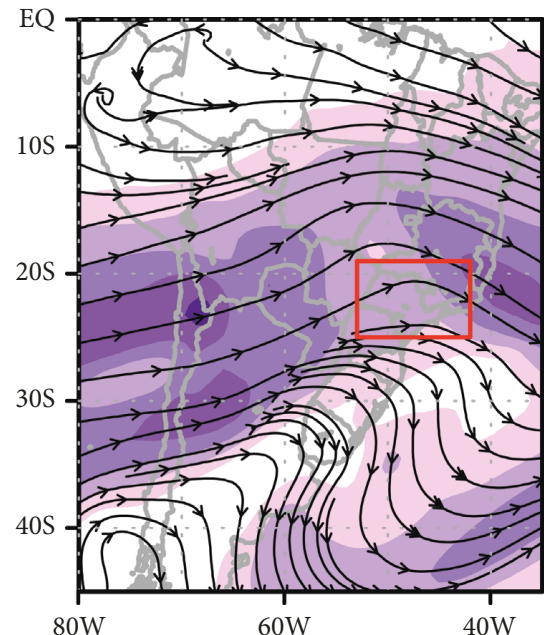

(a)

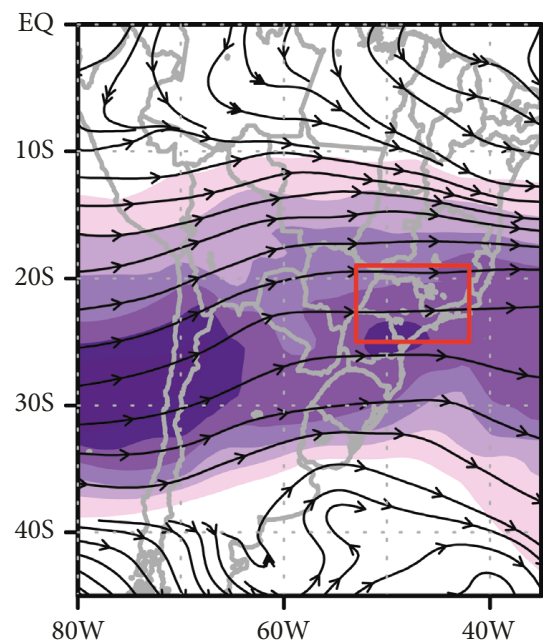

(d)

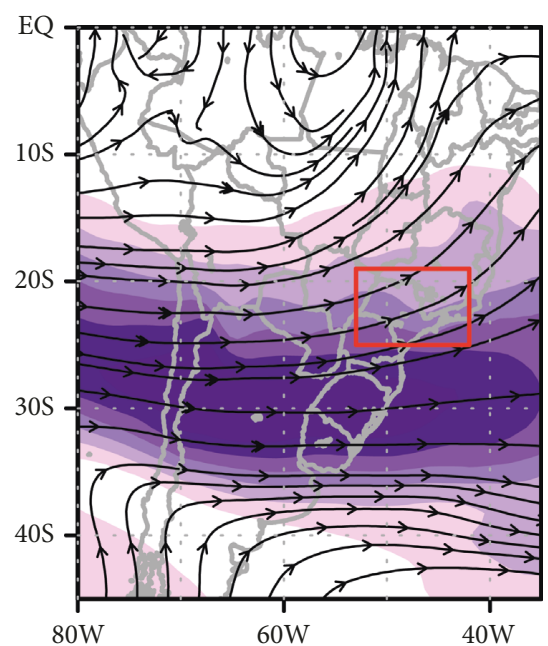

(g)

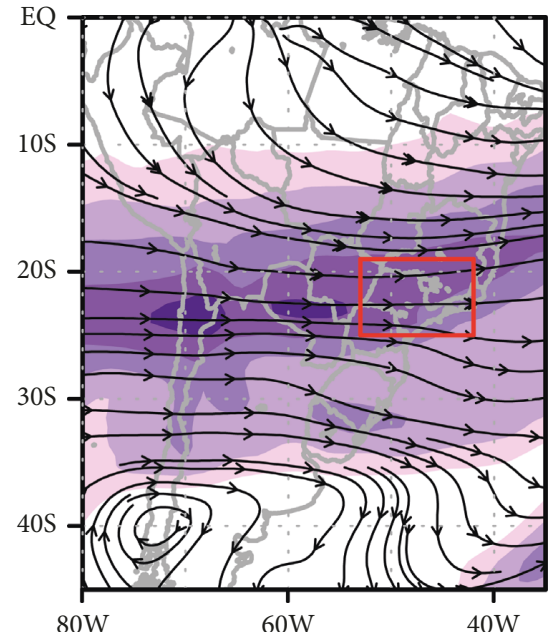

(b)

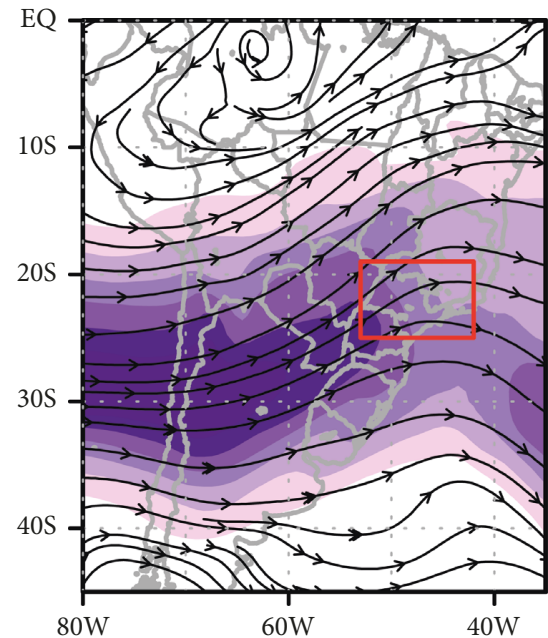

(e)

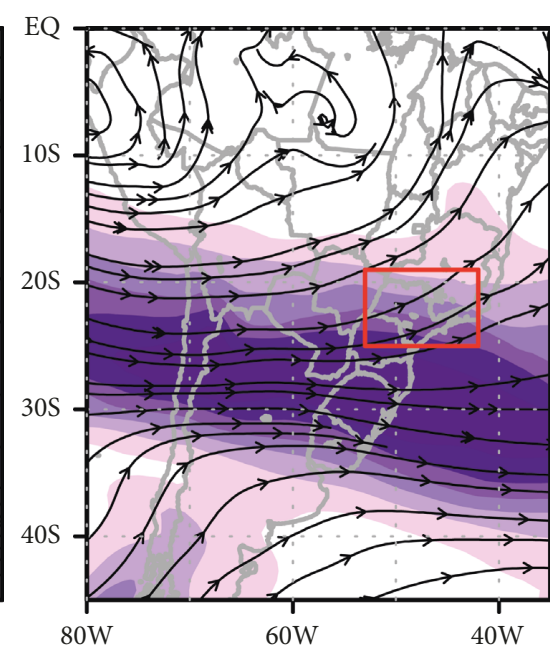

(h)

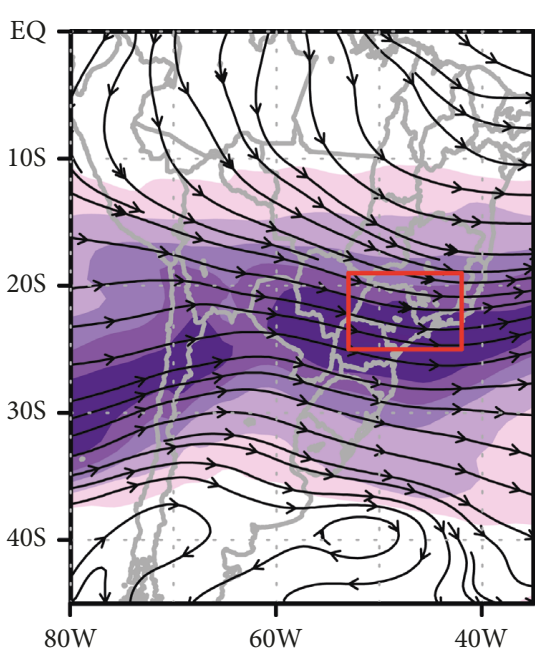

(c)

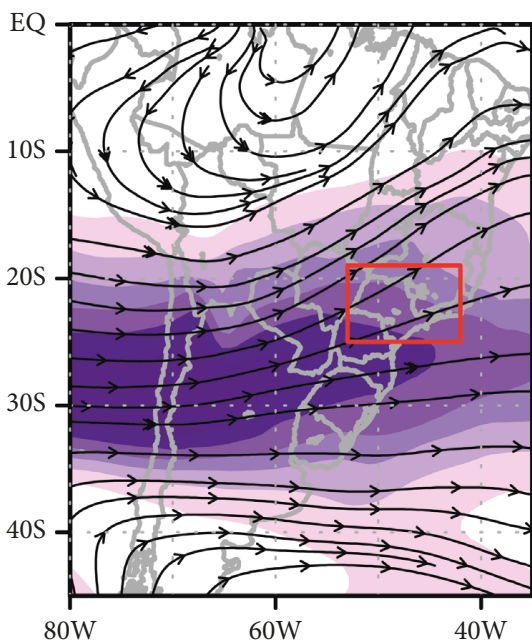

(f)

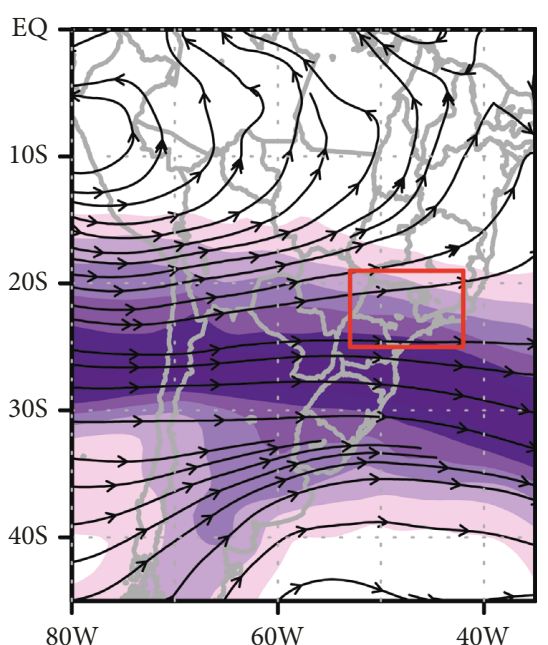

(i)

\section{\begin{tabular}{ll|l|l|l|l}
\hline & & & & & \\
20 & 30 & 40 & 50 & 60 & 70
\end{tabular}}

FIGURE 6: $200 \mathrm{hPa}$ streamlines and isotachs (shaded; $\mathrm{m} \cdot \mathrm{s}^{-1}$ ) at $12 \mathrm{UTC}$ on (a) 30 May, (b) 31 May, (c) 01 June, (d) 02 June, (e) 03 June, (f) 04 June, (g) 05 June, (h) 06 June, and (i) 07 June, 2016. 


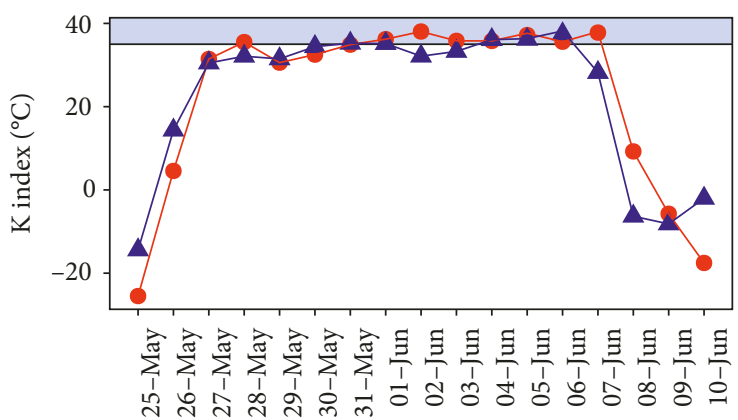

(a)

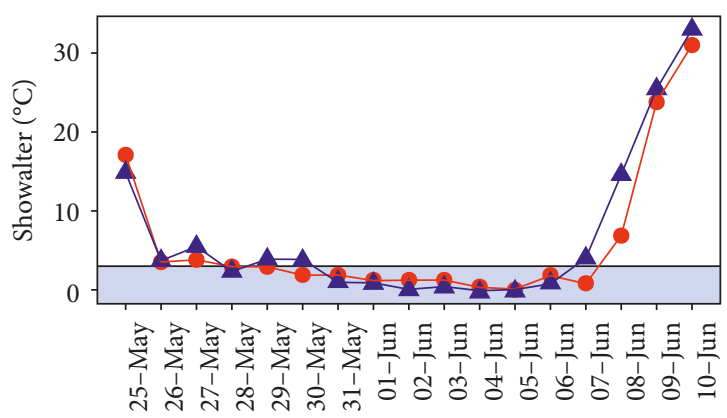

(c)

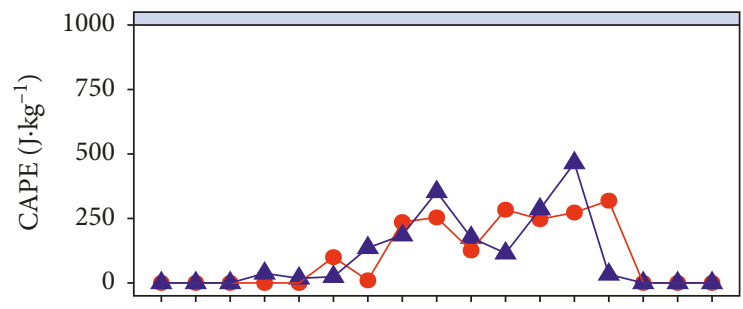

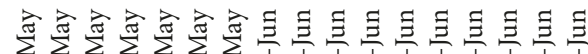

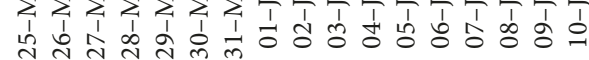
(e)

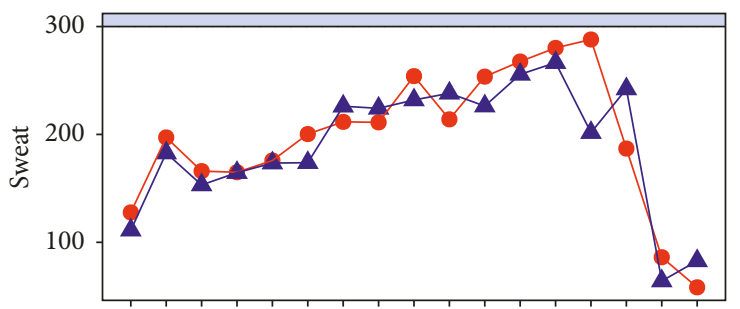

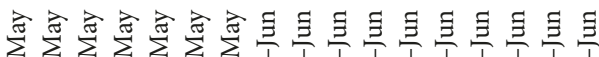

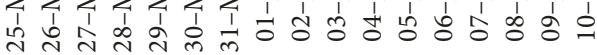

(g)

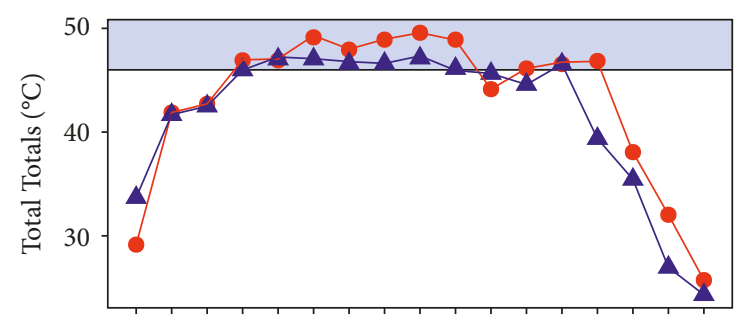

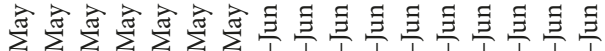

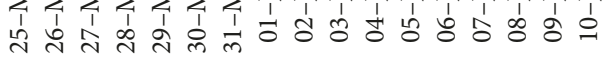

(b)

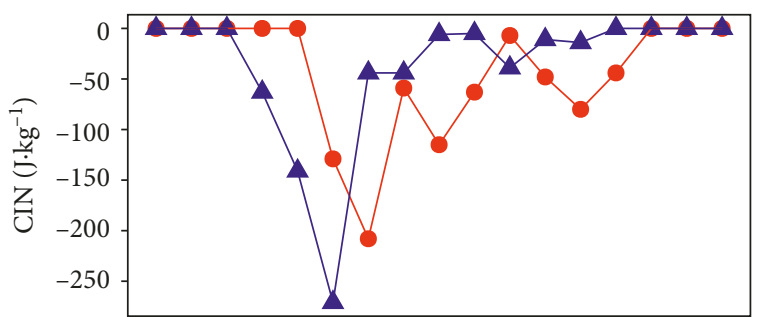

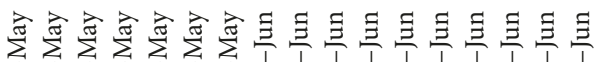

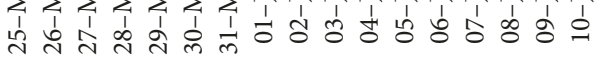

(d)

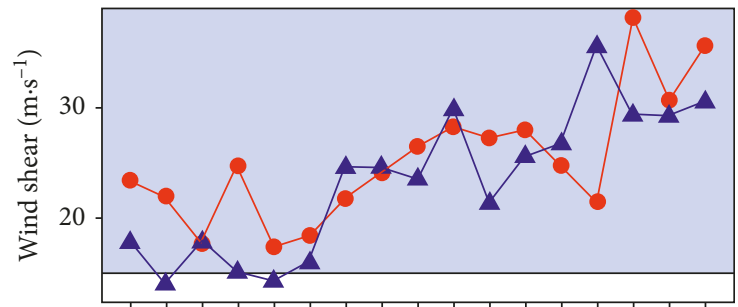

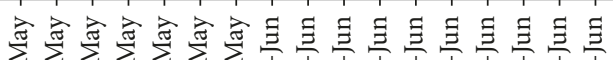

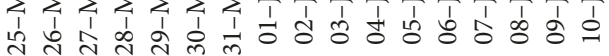

(f)

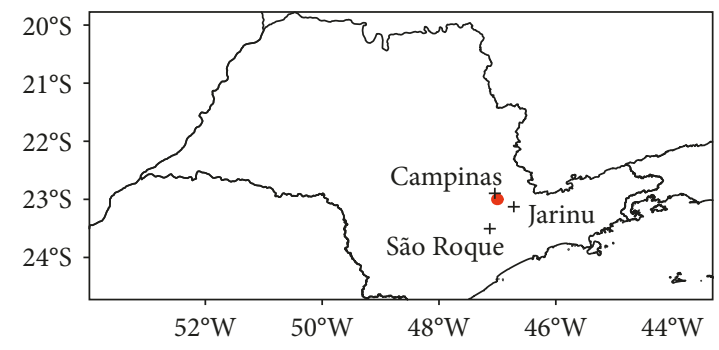

(h)

$\rightarrow 0000$ UTC

- $1200 \mathrm{UTC}$

Figure 7: Temporal evolution of the instability indices at 0000 UTC (red) and 1200 UTC (blue): (a) $K$ index $\left({ }^{\circ} \mathrm{C}\right)$ ), (b) Total Totals $\left({ }^{\circ} \mathrm{C}\right.$ ), (c) Showalter index $\left({ }^{\circ} \mathrm{C}\right),(\mathrm{d})$ CAPE $\left(\mathrm{J} \cdot \mathrm{kg}^{-1}\right),(\mathrm{e}) \mathrm{CIN}\left(\mathrm{J} \cdot \mathrm{kg}^{-1}\right),(\mathrm{f})$ Wind shear $\left(\mathrm{m} \cdot \mathrm{s}^{-1}\right)$, (g) Sweat index, and (h) Map of São Paulo state, with the location of where these indices were calculated (red dot) and the three cities where the most severe thunderstorms occurred (black crosses). The shaded areas from (a) to (g) indicate the values for instability. 
TABLe 1: Values of the climate indices analyzed. $\sigma$ is the standard deviation.

\begin{tabular}{lcc}
\hline Index & Values & Period \\
\hline PSA 1 & +4.0 & June 01-05, 2016 \\
PSA 2 & $-59.0(-2.3 \sigma)$ & June 01-05, 2016 \\
IOD & -0.61 & June 2016 \\
AAO & +1.759 & May 30 to June 07, 2016 \\
\hline
\end{tabular}

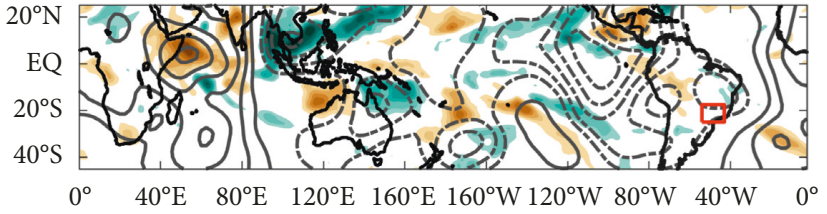

(a)

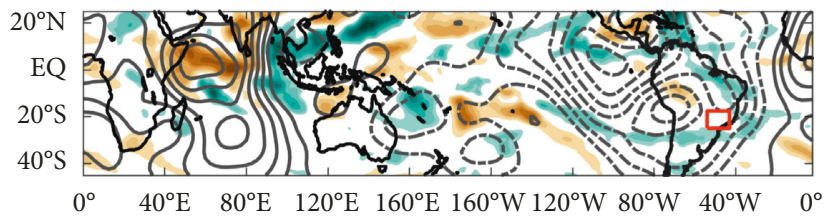

(b)

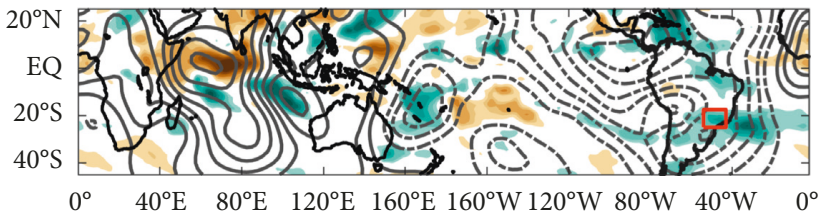

(c)

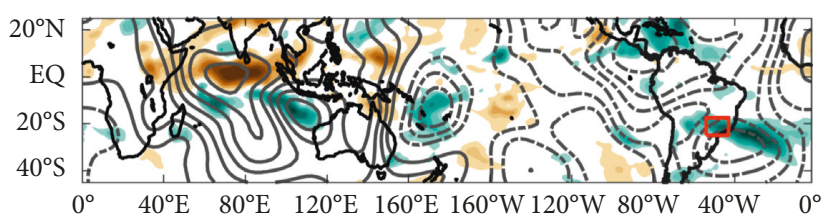

(d)

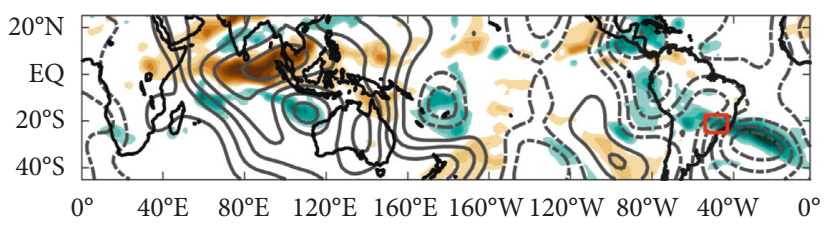

(e)

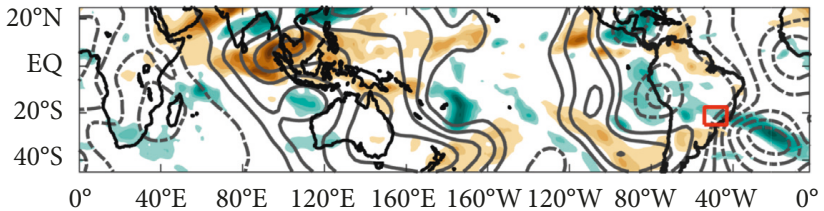

(f)

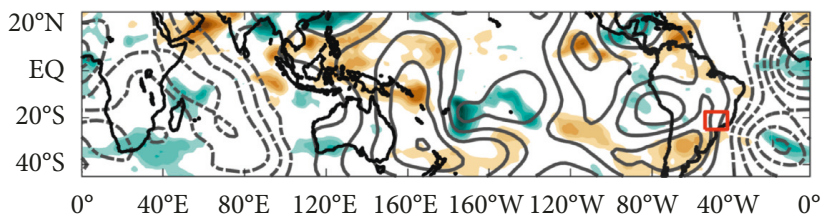

(g)

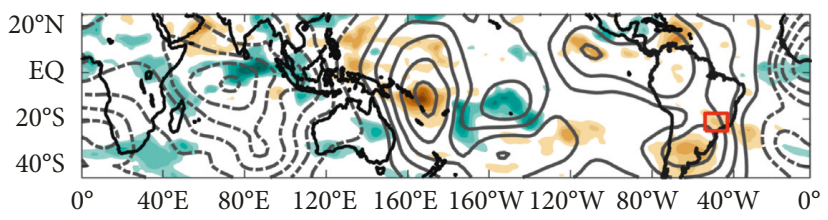

(h)

\begin{tabular}{rrrrrrrrrr}
\hline & 1 & 1 & 1 & 1 & 1 & 1 & 1 \\
-50 & -40 & -30 & -20 & -10 & 0 & 10 & 20 & 30 & 40
\end{tabular}

FIGURE 8: Lagged composite maps of filtered OLR anomaly $\left(\mathrm{W} \cdot \mathrm{m}^{-2}\right.$; shaded) and sigma-level 0.21 velocity potential (black contours every $0.75 \times 10^{6} \cdot \mathrm{m}^{2} \cdot \mathrm{s}^{-1}$; negative values are dashed) for a frequency band of 20 to 96 days. Composites are centered on day -12 to day +9 in which day 0 represents the most intense precipitation events over SP region (June 06). (a) Day-12 (May 25), (b) Day -9 (May 28), (c) Day -6 (May 31), (d) Day -3 (Jun 03), (e) Day 0 (Jun 06), (f) Day +3 (Jun 09), (g) Day +6 (Jun 12), and (h) Day +9 (Jun 15).

American coast that influenced the weather in the SP region during the period analyzed.

The PSA 1 mode in June 2016 was not significant, staying between \pm 1 standard deviation (Table 1 ).

3.2.3. Indian Ocean Dipole and Wave Source Analysis. For May/June 2016, the IOD presents negative values, configuring a negative dipole event (western basin colder and eastern basin warmer). Through the analysis of the wave activity flux divergence (Figure 9) for the May-June 2016 basic state [59], a wave like pattern coming from the Indian Ocean eastern basin (Indo-Pacific region) is not found; thus, this region is probably not a Rossby wave train source influencing the South America-even though it is found to be an upper-level divergence source (see the red shaded area over the eastern basin).
3.2.4. Southern Annular Mode. The AAO index, which measures the phase of the SAM, was positive during the period of study, with an average of +1.759 (Table 1), indicating the predominance of negative anomalies of geopotential height at southern high latitudes and positive anomalies in the middle latitudes $[38,60,61]$. Reboita et al. [23] showed that the low-pressure circumpolar belt is shifted south during the positive phase of the AAO in relation to that in the negative phase, which is unfavorable for the propagation of cyclonic systems to the north that could propagate to Southeastern Brazil. Therefore, the AAO did not interfere in the analyzed extreme event.

3.2.5. Blocking Events. No blocking events affecting the weather over South America were found during the period evaluated (figure not shown). 


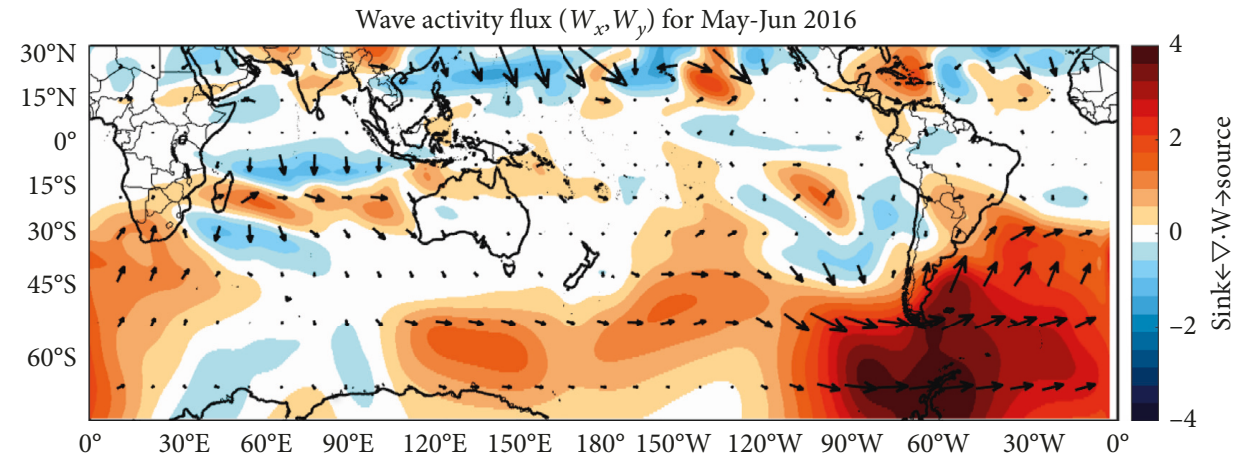

Figure 9: Wave activity flux $\left(\times 10^{6}\right)$ for May-Jun 2016. The arrows represent the wave flux $W_{x}$ and $W_{y}$, and the shading represents the wave flux divergence, wave flux divergence indicates Rossby wave sources and convergence indicates Rossby wave sinks. Following Takaya and Nakamura [59], the wave flux is parallel to the phase velocity of the Rossby wave packages.

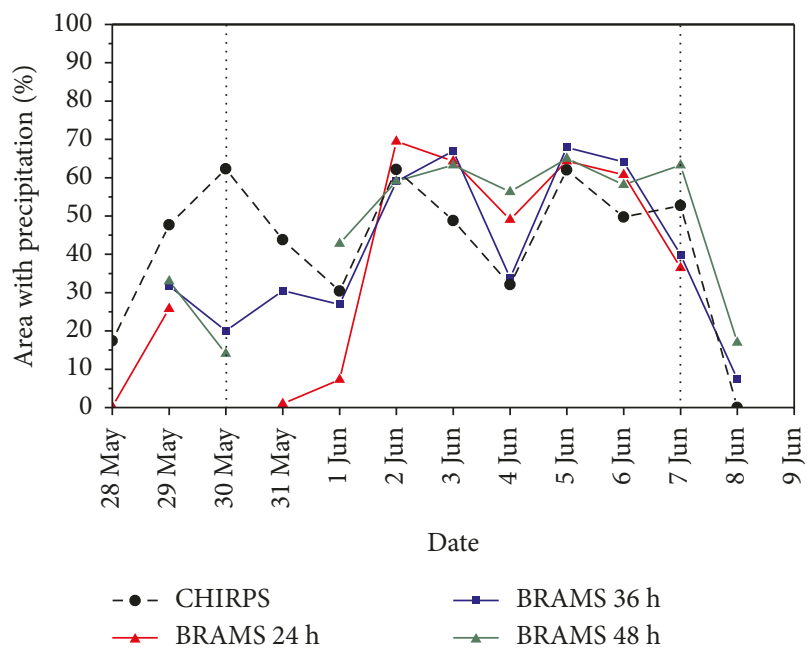

(a)

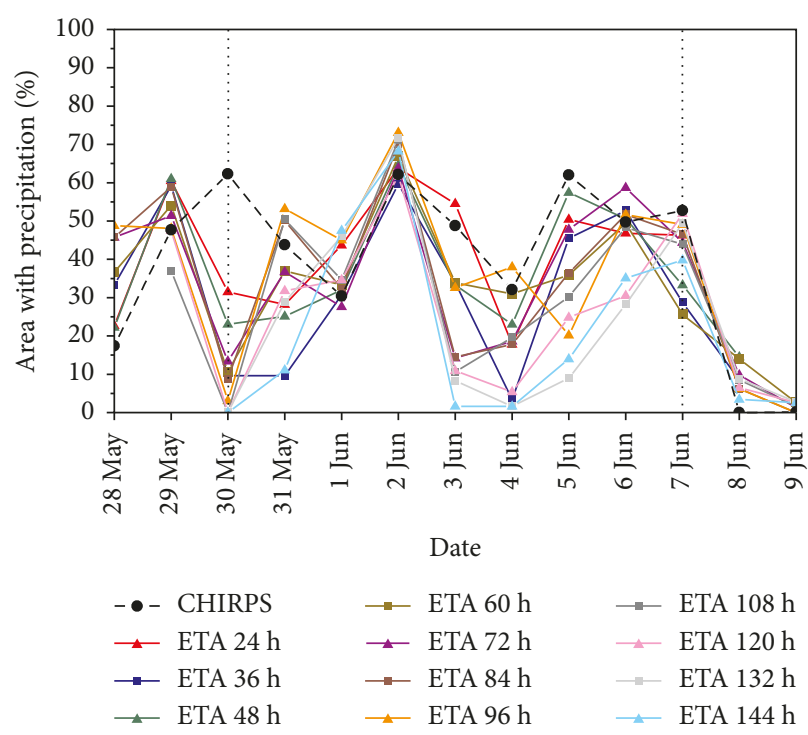

(c)

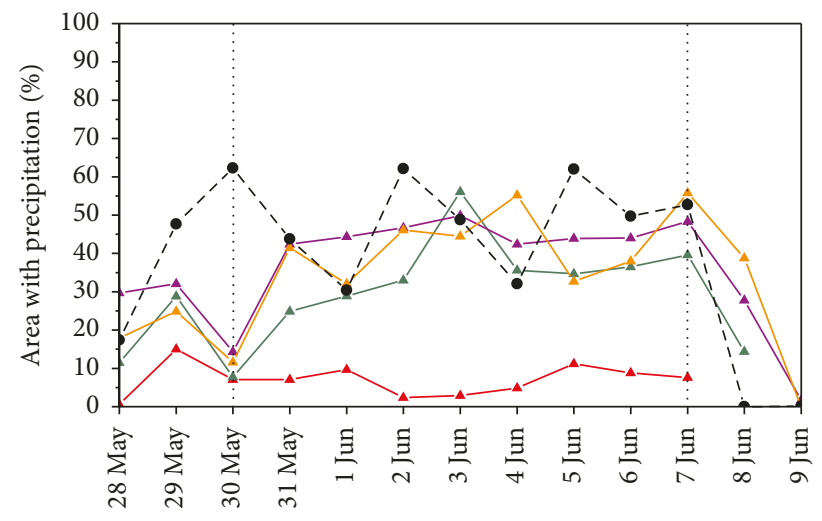

Date

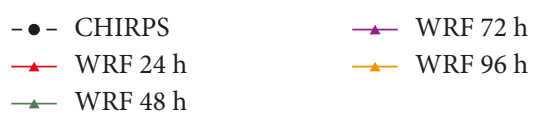

(b)

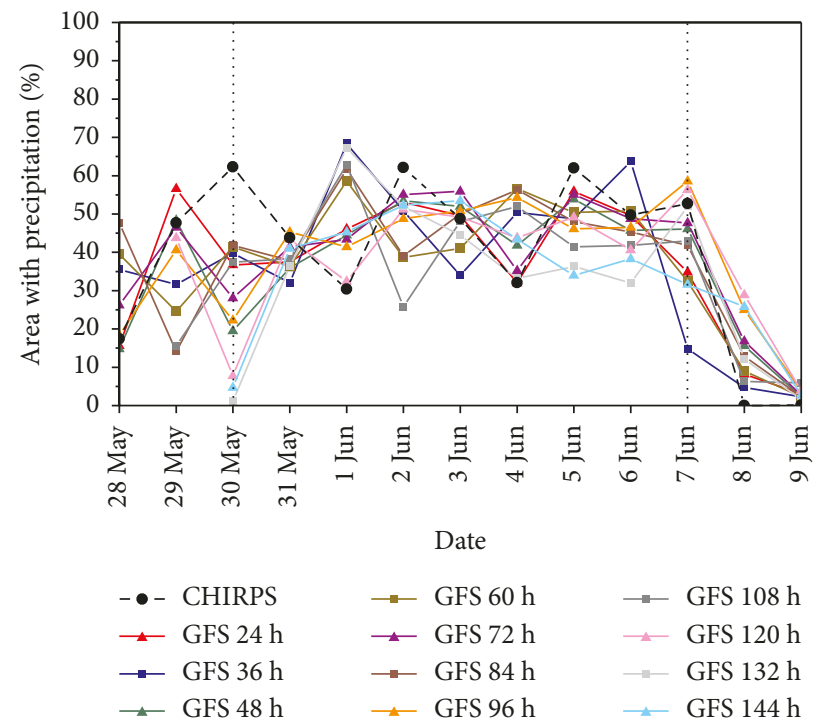

(d)

FIGURE 10: Temporal evolution of the percentage of the SP region area with precipitation above the threshold of $5 \mathrm{~mm} \cdot \mathrm{day}{ }^{-1}$ (\%) for CHIRPS and for different forecast times of the models (a) BRAMS, (b) WRF, (c) Eta, and (d) GFS, from 29 May to 9 June 2016. Dotted lines indicate the start (30 May 2016) and end (07 June 2016) of the period of interest. 


\section{Conclusions}

A sequence of successive convective systems favoring atypical precipitation events, with high volumes of rain, occurrences of tornadoes, and a microburst over Southeastern Brazil took place during the dry season of 2016, more specifically, from May 30 to June 07, 2016 (9 days). These anomalous events caused flooding, damages to houses and buildings, and shortages of electricity and water in several places, with many injuries and two deaths documented.

These severe weather events were associated with a daily sequence of convective systems that formed preferentially during early afternoon in the western part of SP state (red box in Figure 1) and also northwest of the SP region, propagating along the low-level mean flow and growing as they moved into the region. The convective systems were embedded in an instable environment (high $K$ index, high Total Totals, low Showalter, and high wind shear) with an intense and persistent South American low-level jet (SALLJ) (east of the Andes) advecting heat and moisture from the Amazon Basin into Southeastern Brazil. The exit region of the SALLJ was located over the SP region instead of Southern Brazil-northern Argentina (which is its typical exit location according to climatological studies). This displacement along the direction of the jet was likely driven by a sequence of extratropical cyclones that formed to the south of the region of interest over the Southwest Atlantic Ocean during the 9-day rainy period. The SALLJ was identified as the main mechanism contributing to the observed precipitation; when this jet weakened (in association with a colder and drier air mass advected over its exit region), the convective activity decreased over the SP region, characterizing the end of the atypical precipitation events.

The effects of the local dynamic and thermodynamic processes mentioned in the previous paragraph were intensified by the MJO in its phase 8 and by the intense negative PSA 2 mode. There was no evidence of a constructive or destructive contribution from the PSA 1, from the IOD or from atmospheric blocking. Moreover, the AAO index was positive $(+1.759)$ during the 9 -day rainy period, which would disfavor cyclone propagation to the north; thus, the AAO was not a constructive factor in the analyzed extreme event.

Given the above analysis, one might ask if numerical models were able to predict this anomalous precipitation event. A preliminary analysis considering four different numerical models indicate that they all failed to forecast the beginning of the precipitation period. However, they successfully forecasted its end (Figure 10). Overall, the Global Forecasting System (GFS) was the best model over the 9-day rainy period, followed by the Brazilian Regional Atmospheric Modeling System (BRAMS), the Eta Model, and the Weather Research and Forecasting Model (WRF). The 24-hour forecasts of the WRF were the worst among all forecasts, underestimating both the area and intensity (not shown) of precipitation. Among the possible reasons why these models did not present good performance is that they might have not represented the main dynamic forcings (e.g., SALLJ), leading to this anomalous rainy event. Results of a detailed verification will be presented and discussed in a future paper.

Atypical precipitation events like the one analyzed in the present paper can happen again in the future, causing further significant impacts for society and the economy. Studies to detect and evaluate the mechanisms contributing to these anomalous events are important for the improvement of the forecasts and mitigation of the associated consequences. Suggestions for future studies include investigating why the models did not predict the beginning of the precipitation period and whether this type of severe weather will be frequent in the coming warmer climate.

\section{Conflicts of Interest}

The authors declare that there are no conflicts of interest regarding the publication of this paper.

\section{Acknowledgments}

The authors are grateful to Dr. José Roberto Rozante, Dr. Jorge Luís Gomes, and Vinicius Matoso Silva from CPTEC/INPE for providing BRAMS and Eta datasets and to the Universidade Federal de Itajubá (UNIFEI) for providing WRF datasets. Tercio Ambrizzi was supported by CNPq and FAPESP.

\section{References}

[1] C. A. S. Coelho, C. P. de Oliveira, T. Ambrizzi et al., "The 2014 southeast Brazil austral summer drought: regional scale mechanisms and teleconnections," Climate Dynamics, vol. 46, no. 11-12, pp. 1-16, 2015.

[2] A. Seth, K. Fernandes, and S. J. Camargo, "Two summers of São Paulo drought: origins in the western tropical Pacific," Geophysical Research Letter, vol. 42, no. 24, pp. 10816-10823, 2015.

[3] C. S. Vera, W. Higgins, J. Amador et al., "Towards a unified view of the American Monsoon Systems," Journal of Climate, vol. 19, no. 20, pp. 4977-5000, 2006.

[4] Y. M. Kodama, "Large-scale common features of sub- tropical precipitation zones (the Baiu Frontal Zone, the SPCZ, and the SACZ). Part I: characteristics of subtropical frontal zones," Journal of the Meteorological Society of Japan, vol. 70, no. 4, pp. 813-835, 1992.

[5] T. Ambrizzi and S. E. T. Ferraz, "An objective criterion for determining the South Atlantic Convergence Zone," Frontiers in Environmental Science, vol. 3, pp. 3-23, 2015.

[6] M. S. Reboita, M. A. Gan, R. P. da Rocha, and T. Ambrizzi, "Regimes de precipitação na América do Sul: uma revisão bibliográfica," Revista Brasileira de Meteorologia, vol. 25, no. 2, pp. 185-204, 2010.

[7] D. P. Dee, S. M. Uppala, A. J. Simmons et al., "The ERAInterim reanalysis: configuration and performance of the data assimilation system," Quarterly Journal of the Royal Meteorological Society, vol. 137, no. 656, pp. 553-597, 2011.

[8] J. E. Janowiak, R. J. Joyce, and Y. Yarosh, "A real-time global half-hourly pixel-resolution infrared dataset and its applications," Bulletin of the American Meteorological Society, vol. 82, no. 2, pp. 205-217, 2001.

[9] J. P. Craven and H. E. Brooks, "Baseline climatology of sounding derived parameters associated with deep moist convection," National Weather Digest, vol. 28, pp. 13-24, 2004. 
[10] E. L. Nascimento, "Prediction of severe storms using convective parameters and mesoscale models: an operational strategy adopted in Brazil," Brazilian Journal of Meteorology, vol. 20, pp. 121-140, 2005.

[11] H. Bluestein, "Advances in applications of the physics of fluids to severe weather systems," Reports on Progress in Physics, vol. 70, no. 8, pp. 1259-1323, 2007.

[12] J. P. Monteverdi, C. A. Doswell, and G. S. Lipari, "Shear parameter thresholds for forecasting tornadic thunderstorms in northern and central California," Weather and Forecasting, vol. 18, no. 2, pp. 357-370, 2003.

[13] S. Grünwald and H. E. Brooks, "Relationship between sounding derived parameters and the strength of tornados in Europe and the USA from reanalysis data," Atmospheric Research, vol. 100, no. 4, pp. 479-488, 2011.

[14] J. J. George, Weather Forecasting for Aeronautics, Academic Press, Cambridge, MA, USA, 1960.

[15] R. C. Miller, "Notes on analysis and severe storm forecasting procedures of the Air Force Global Weather Central," Technical Report 200, p. 190, Air Weather Service, United States Air Force Washington, DC, USA, 1972.

[16] A. K. Showalter, "A stability index for forecasting thunderstorms," Bulletin of the American Meteorological Society, vol. 34, pp. 250-252, 1947.

[17] C. Jones and L. M. V. Carvalho, "Stochastic simulations of the Madden-Julian oscillation activity," Climate Dynamics, vol. 36, no. 1-2, pp. 229-246, 2011.

[18] K. C. Mo and R. W. Higgins, "The Pacific-South American modes and tropical convection during the Southern Hemisphere winter," Monthly Weather Review, vol. 126, no. 6, pp. 1581-1596, 1998.

[19] D. L. Herdies, A. Da Silva, M. A. F. Silva Dias, and R. NietoFerreira, "Moisture budget of the bimodal pattern of the summer circulation over South America," Journal Geophysical Research, vol. 107, no. 20, pp. 42/1-42/10, 2002.

[20] A. R. M. Drumond and T. Ambrizzi, "The role of the South Indian and Pacific oceans in South American monsoon variability," Theoretical and Applied Climatology, vol. 94, no. 3-4, pp. 125-137, 2008.

[21] S. C. Chan, S. K. Behera, and T. Yamagata, "Indian ocean dipole influence on South American rainfall," Geophysical Research Letters, vol. 35, no. 14, p. L14S12, 2008.

[22] A. S. Taschetto and T. Ambrizzi, "Can Indian Ocean SST anomalies influence South American rainfall?," Climate Dynamics, vol. 38, no. 7-8, pp. 1615-1628, 2012.

[23] M. S. Reboita, T. Ambrizzi, and R. P. Rocha, "Relationship between the Southern Annular Mode and Southern Hemisphere Atmospheric Systems," Revista Brasileira de Meteorologia, vol. 24, no. 1, pp. 48-55, 2009.

[24] M. C. D. Mendes, R. Trigo, I. Cavalcanti, and C. Camara, "Climatologia de bloqueios sobre o Oceano Pacífico Sul: período de 1960 a 2000," Revista Brasileira de Meteorologia, vol. 20, pp. 175-190, 2005.

[25] F. N. M. Oliveira, L. M. V. Carvalho, and T. Ambrizzi, "A new climatology for Southern Hemisphere blockings in the winter and the combined effect of ENSO and SAM phases," International Journal of Climatology, vol. 34, pp. 1676-1692, 2013.

[26] R. Madden and P. Julian, "Detection of a 40-50 day oscillation in the zonal wind in the tropical Pacific," Journal of the Atmospheric Sciences, vol. 28, no. 5, pp. 702-708, 1971.

[27] E. Kalnay, M. Kanamitsu, R. Kistler et al., "The NCEP/NCAR 40-year reanalysis project," Bulletin of the American Meteorological Society, vol. 77, no. 3, pp. 437-471, 1996.
[28] H.-T. Lee, A. Gruber, R. G. Ellingson, and I. Laszlo, "Development of the HIRS outgoing longwave radiation climate dataset," Journal of Atmospheric and Oceanic Technology, vol. 24, no. 12, pp. 2029-2047, 2007.

[29] C. E. Duchon, "Lanczos filtering in one and two dimensions," Journal of Applied Meteorology, vol. 18, no. 8, pp. 1016-1022, 1979.

[30] M. C. Wheeler and H. H. Hendon, "An all-season real-time multivariate MJO index: development of an index for monitoring and prediction," Monthly Weather Review, vol. 132, no. 8, pp. 1917-1932, 2004.

[31] D. J. Karoly, "Southern Hemisphere circulation features associated with El Nino-Southern Oscillation events," Journal of Climate, vol. 2, no. 11, pp. 1239-1251, 1989.

[32] K. C. Mo and J. N. Paegle, "The Pacific-South American modes and their downstream effects," International Journal of Climatology, vol. 21, no. 10, pp. 1211-1229, 2001.

[33] M. Ghil and K. C. Mo, "Intraseasonal oscillations in the global atmosphere. Part II: Southern Hemisphere," Journal of the Atmospheric Sciences, vol. 48, no. 5, pp. 780-790, 1991.

[34] M. K. Lau, P. J. Sheu, and I. S. Kang, "Multiscale lowfrequency circulation modes in the global atmosphere," Journal of the Atmospheric Sciences, vol. 51, no. 9, pp. 11691193, 1994.

[35] N. H. Saji, T. Ambrizzi, and S. E. T. Ferraz, "Indian Ocean Dipole mode events and austral surface air temperature anomalies," Dynamics of Atmospheres and Oceans, vol. 39, no. 1-2, pp. 87-101, 2005.

[36] N. H. Saji, B. N. Goswami, P. N. Vinayachandran, and T. Yamagata, "A dipole mode in the tropical Indian Ocean," Nature, vol. 401, no. 6751, pp. 360-363, 1999.

[37] P. J. Webster, A. M. Moore, J. P. Loschnigg, and R. R. Leben, "Coupled ocean-atmosphere dynamics in the Indian Ocean during 1997-98," Nature, vol. 401, no. 6751, pp. 356-360, 1999.

[38] D. W. J. Thompson, and J. M. Wallace, "Annular modes in the extratropical circulation. Part I: month-to-month variability," Journal of Climate, vol. 13, no. 5, pp. 1000-1016, 2000.

[39] K. C. Mo, "Relationships between low-frequency variability in the Southern Hemisphere and sea surface temperature anomalies," Journal of Climate, vol. 13, no. 20, pp. 3599-3610, 2000.

[40] D. J. Karoly, "Rossby wave propagation in a barotropic atmosphere," Dynamics of Atmospheres and Oceans, vol. 7, no. 2, pp. 111-125, 1983.

[41] M. D. Mendes, R. Trigo, I. Cavalcanti, and C. Camara, "Blocking episodes in the southern hemisphere: impact on the climate of adjacent continental areas," Pure and Applied Geophysics, vol. 165, pp. 1941-1962, 2008.

[42] S. Tibaldi, E. Tosi, A. Navarra, and L. Pedulli, "Northern and Southern Hemisphere variability of blocking frequency and predictabilty," Monthly Weather Review, vol. 122, no. 9, pp. 1971-2003, 1994.

[43] H. Lejenãs, "Characteristics of Southern Hemisphere blocking as determined from a Time series of observational data," Quarterly Journal of the Royal Meteorological, vol. 110, no. 9, pp. 967-979, 1984.

[44] M. R. Sinclair, "Reply," Monthly Weather Review, vol. 124, no. 11, pp. 2615-2618, 1996.

[45] R. F. C. Marques and V. B. Rao, "A diagnosis of a long-lasting blocking event over the Southeast Pacific Ocean," Monthly Weather Review, vol. 127, no. 8, pp. 1761-1776, 1999.

[46] A. M. Grimm and T. Ambrizzi, "Teleconnections into South America from the tropics and extratropics on interannual and intraseasonal timescales," in Past Climate Variability in South America and Surrounding Regions: Developments in Paleoenvironmental Research, F. Vimeux, F. Sylvestre, and 
M. Khodri, Eds., vol. 14, Springer, Dordrecht, Netherlands, 2009.

[47] R. P. da Rocha, M. S. Reboita, L. M. M. Dutra et al., "Interannual variability associated with ENSO: present and future climate projections of RegCM4 for South AmericaCORDEX domain," Climatic Change, vol. 125, no. 1, pp. 95-109, 2014.

[48] C. A. S. Coelho, C. B. Uvo, and T. Ambrizzi, "Exploring the impacts of the Tropical Pacific SST on the precipitation patterns over South America during ENSO periods," Theoretical and Applied Climatology, Austria, vol. 71, no. 3-4, pp. 185-197, 2002.

[49] C. A. R. Morales, R. P. da Rocha, and R. Bombardi, "On the development of summer thunderstorms in the city of São Paulo: mean meteorological characteristics and pollution effect," Atmospheric Research, vol. 96, no. 2-3, pp. 477-488, 2010.

[50] J. A. Marengo, M. Douglas, and P. Silva Dias, "The South American low-level jet east of the Andes during the LBATRMM and WETAMC campaign of January-April 1999," Journal of Geophysical Research, vol. 107, no. 20, 2002.

[51] J. A. Marengo, W. R. Soares, C. Saulo, and M. Nicolini, "Climatology of the low-level jet east of the Andes as derived from the NCEP-NCAR reanalyses: characteristics and temporal variability," Journal of Climate, vol. 17, no. 12, pp. 2261-2280, 2004.

[52] P. M. Markowski and J. M. Straka, "Some observations of rotating updrafts in a low-buoyancy, highly sheared environment," Monthly Weather Review, vol. 128, no. 2, pp. $449-461,2000$.

[53] A. C. N. Tomaziello and A. W. Gandu, Análise Estatística de Índices de Instabilidade Termodinâmica em São Paulo, in: XV Congresso Brasileiro de Meteorologia, São Paulo, SP. Anais. Soc. Bras. Meteorologia. DVD, 2008.

[54] R. Hallak and A. J. Pereira Filho, "Análise de desempenho de índices de instabilidade atmosférica na previsão de fenômenos convectivos de mesoescala na região metropolitana de São Paulo entre 28 de janeiro e 04 de fevereiro de 2004," Revista Brasileira de Meteorologia, vol. 27, no. 2, pp. 173-206, 2012.

[55] C. S. Vera, M. S. Alvarez, P. L. M. Gonzalez, B. Liebmann, and G. N. Kiladis, "Seasonal cycle of precipitation variability in South America on intraseasonal timescales," Climate Dynamics, pp. 1-11, 2017.

[56] C. Jones and L. M. V. Carvalho, "Spatial-intensity variations in extreme precipitation in the contiguous United States and the Madden-Julian oscillation," Journal of Climate, vol. 25, no. 14, pp. 4898-4913, 2012.

[57] M. S. Alvarez, C. S. Vera, G. N. Kiladis, and B. Liebmann, "Influence of the Madden Julian Oscillation on precipitation and surface air temperature in South America," Climate Dynamics, vol. 46, no. 1-2, pp. 245-262, 2016.

[58] E. B. Souza and T. Ambrizzi, "Modulation of the intraseasonal rainfall over tropical Brazil by the Madden-Julian oscillation," International Journal of Climatology, vol. 26, pp. 1759-1776, 2006.

[59] K. Takaya and H. Nakamura, "A formulation of a phaseindependent wave-activity flux for stationary and migratory quasigeostrophic eddies on a zonally varying basic flow," Journal of the Atmospheric Sciences, vol. 58, no. 6, pp. 608627, 2001.

[60] D. W. J. Thompson and S. Solomon, "Interpretation of recent Southern Hemisphere climate change," Science, vol. 296, no. 5569, pp. 895-899, 2002.
[61] N. P. Gillett, T. D. Kell, and P. D. Jones, "Regional climate impacts of the Southern Annular Mode," Geophysical Research Letters, vol. 33, no. 23, pp. 1-4, 2006. 

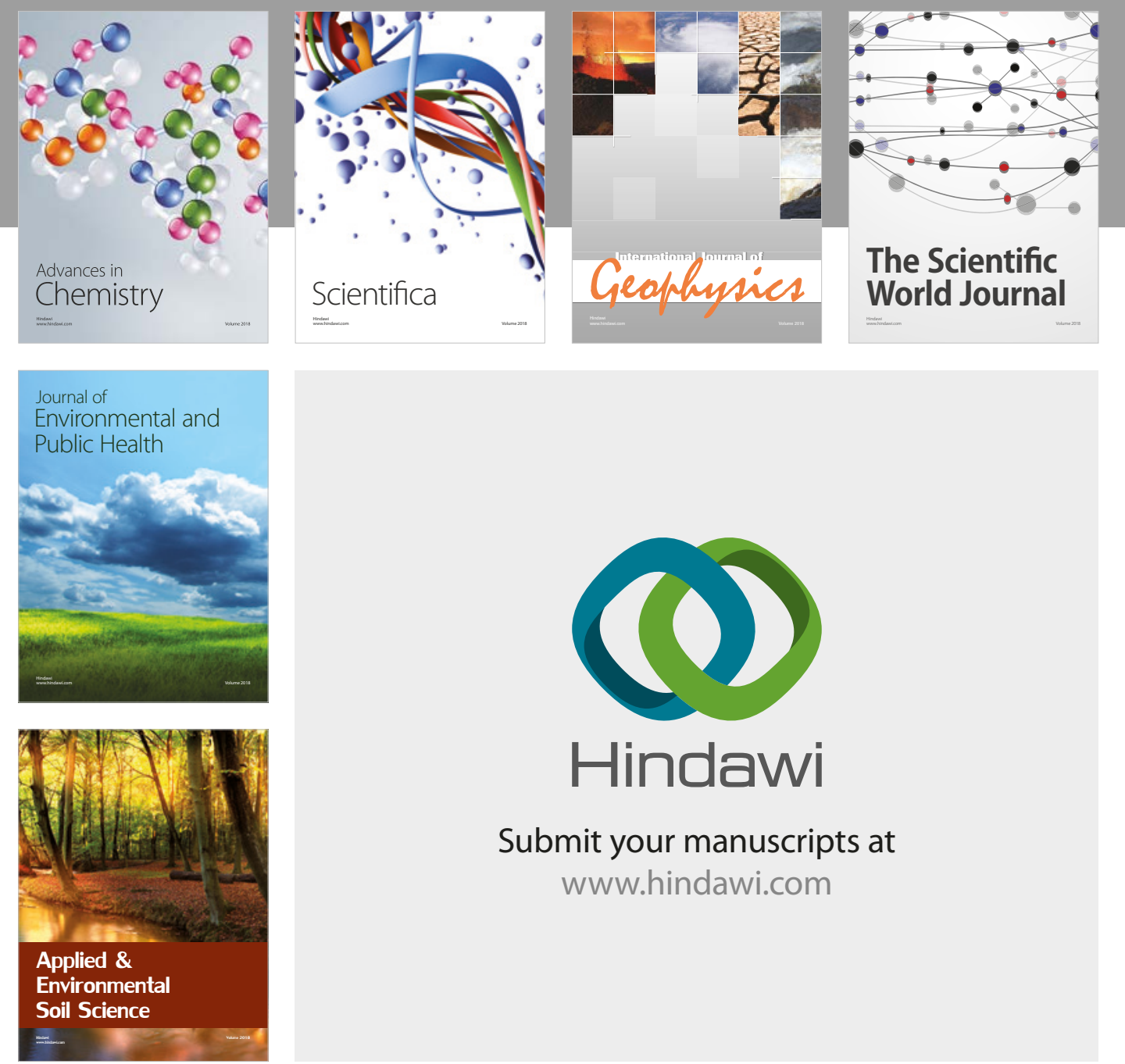

The Scientific

\section{World Journal}
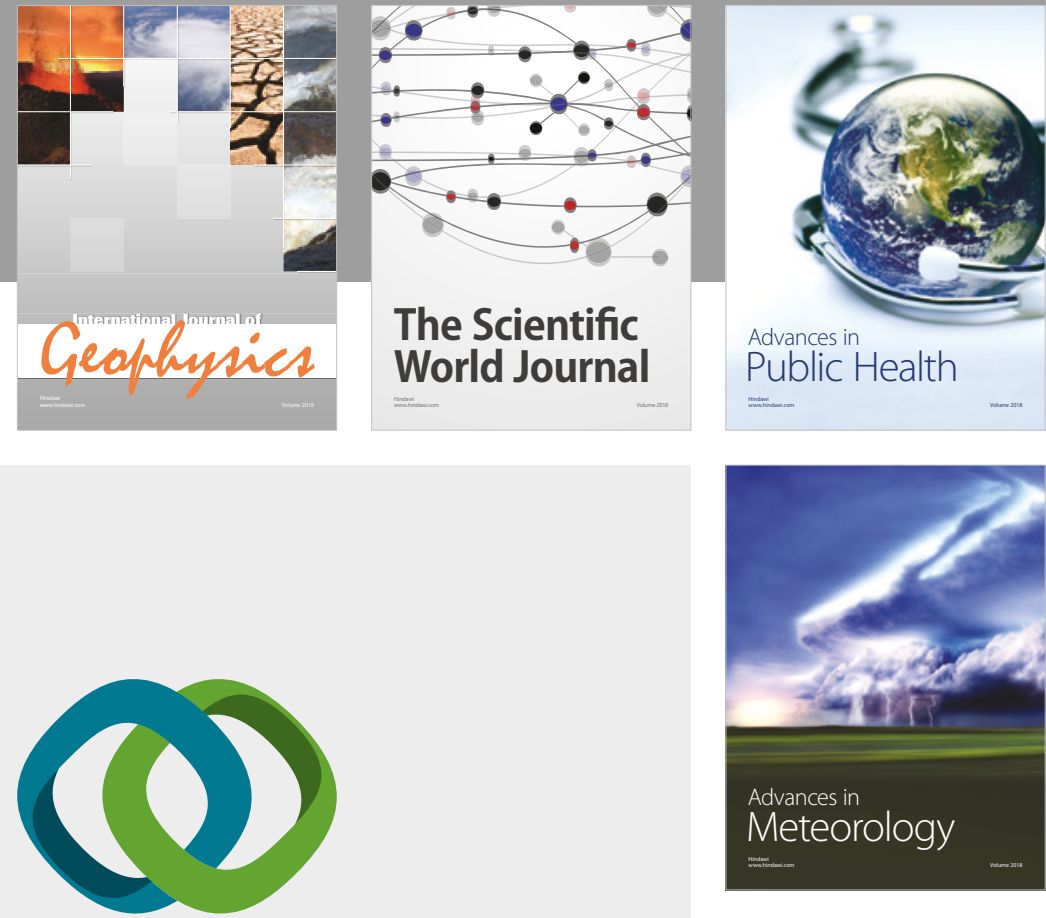

Advan

Public Health

\section{Hindawi}

Submit your manuscripts at

www.hindawi.com
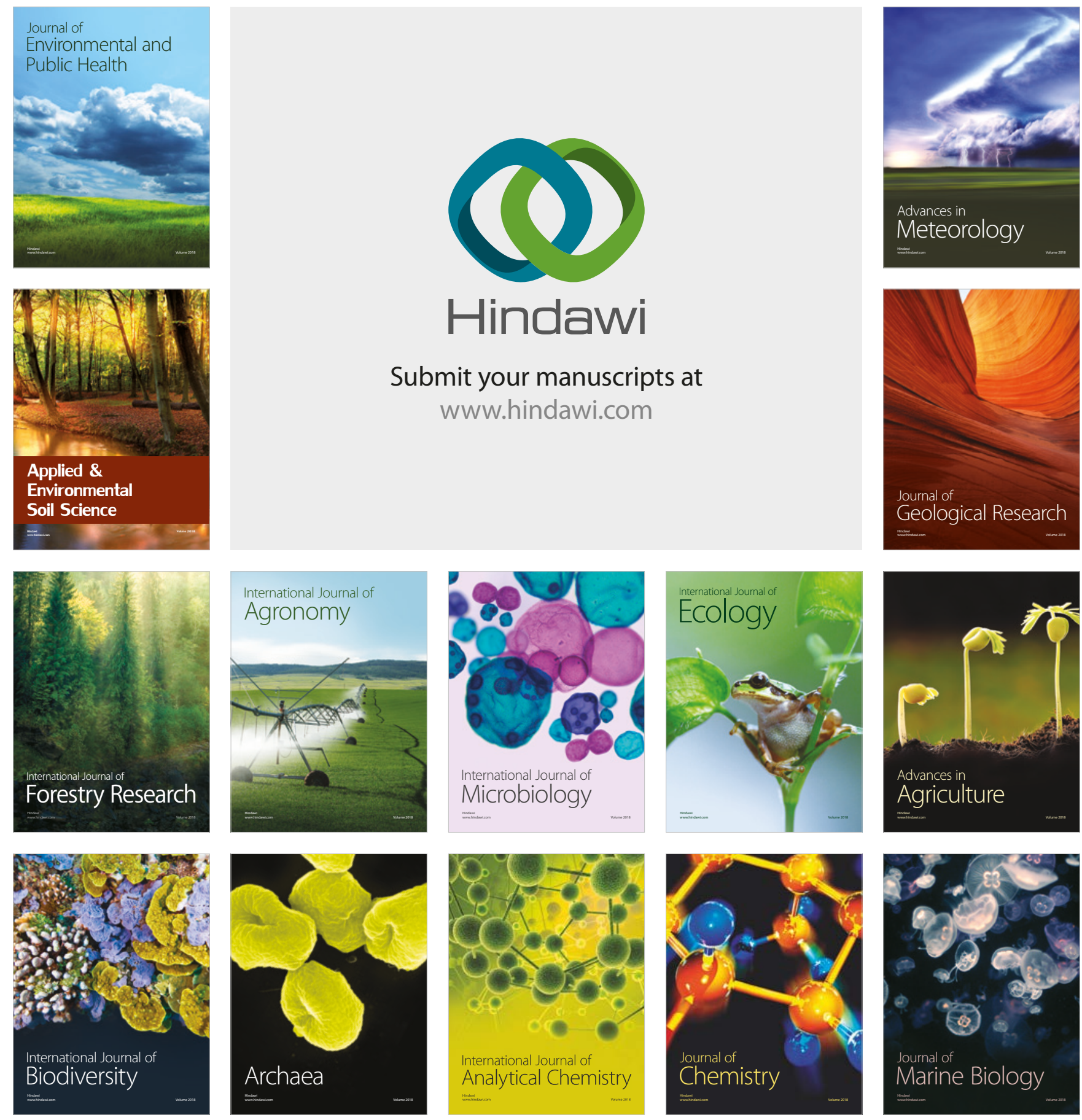